\title{
Comparison between summertime and wintertime Arctic Ocean primary marine aerosol properties
}

\author{
J. Zábori ${ }^{1}$, R. Krejci ${ }^{1,2}$, J. Ström ${ }^{1}$, P. Vaattovaara ${ }^{3}$, A. M. L. Ekman $^{4,5}$, M. E. Salter ${ }^{1}$, E. M. Mårtensson ${ }^{1,6}$, and \\ E. D. Nilsson ${ }^{1}$ \\ ${ }^{1}$ Department of Applied Environmental Science, Stockholm University, 11418 Stockholm, Sweden \\ ${ }^{2}$ Department of Physics, University of Helsinki, 00014 Helsinki, Finland \\ ${ }^{3}$ Department of Applied Physics, University of Eastern Finland, 70211 Kuopio, Finland \\ ${ }^{4}$ Department of Meteorology, Stockholm University, 11418 Stockholm, Sweden \\ ${ }^{5}$ Bert Bolin Centre for Climate Research, Stockholm University, 11418 Stockholm, Sweden \\ ${ }^{6}$ Department of Earth Sciences, Uppsala University, 75236 Uppsala, Sweden
}

Correspondence to: J. Zábori (julia.zabori@itm.su.se)

Received: 15 November 2012 - Published in Atmos. Chem. Phys. Discuss.: 5 December 2012

Revised: 28 March 2013 - Accepted: 4 April 2013 - Published: 8 May 2013

\begin{abstract}
Primary marine aerosols (PMAs) are an important source of cloud condensation nuclei, and one of the key elements of the remote marine radiative budget. Changes occurring in the rapidly warming Arctic, most importantly the decreasing sea ice extent, will alter PMA production and hence the Arctic climate through a set of feedback processes. In light of this, laboratory experiments with Arctic Ocean water during both Arctic winter and summer were conducted and focused on PMA emissions as a function of season and water properties. Total particle number concentrations and particle number size distributions were used to characterize the PMA population. A comprehensive data set from the Arctic summer and winter showed a decrease in PMA concentrations for the covered water temperature $\left(T_{\mathrm{w}}\right)$ range between $-1{ }^{\circ} \mathrm{C}$ and $15^{\circ} \mathrm{C}$. A sharp decrease in PMA emissions for a $T_{\mathrm{W}}$ increase from $-1{ }^{\circ} \mathrm{C}$ to $4{ }^{\circ} \mathrm{C}$ was followed by a lower rate of change in PMA emissions for $T_{\mathrm{W}}$ up to about $6^{\circ} \mathrm{C}$. Near constant number concentrations for water temperatures between $6^{\circ} \mathrm{C}$ to $10^{\circ} \mathrm{C}$ and higher were recorded. Even though the total particle number concentration changes for overlapping $T_{\mathrm{w}}$ ranges were consistent between the summer and winter measurements, the distribution of particle number concentrations among the different sizes varied between the seasons. Median particle number concentrations for a dry diameter $\left(D_{p}\right)$ $<0.125 \mu \mathrm{m}$ measured during winter conditions were similar (deviation of up to $3 \%$ ), or lower (up to $70 \%$ ) than the ones measured during summer conditions (for the same wa-
\end{abstract}

ter temperature range). For $D_{p}>0.125 \mu \mathrm{m}$, the particle number concentrations during winter were mostly higher than in summer (up to $50 \%$ ). The normalized particle number size distribution as a function of water temperature was examined for both winter and summer measurements. An increase in $T_{\mathrm{w}}$ from $-1^{\circ} \mathrm{C}$ to $10^{\circ} \mathrm{C}$ during winter measurements showed a decrease in the peak of relative particle number concentration at about a $D_{p}$ of $0.180 \mu \mathrm{m}$, while an increase was observed for particles with $D_{p}>1 \mu \mathrm{m}$. Summer measurements exhibited a relative shift to smaller particle sizes for an increase of $T_{\mathrm{w}}$ in the range $7-11^{\circ} \mathrm{C}$. The differences in the shape of the number size distributions between winter and summer may be caused by different production of organic material in water, different local processes modifying the water masses within the fjord (for example sea ice production in winter and increased glacial meltwater inflow during summer) and different origin of the dominant sea water mass. Further research is needed regarding the contribution of these factors to the PMA production.

\section{Introduction}

In recent decades environmental conditions in the Arctic region have changed rapidly, in particular in the Arctic Ocean. Changes in the Arctic Ocean sea ice and Arctic Ocean water properties are manifold: decrease of the sea ice extent, 
decrease of the perennial sea ice, increase of freshwater inflow, increase of water temperature, and a change of the biological state (Parkinson and Cavalieri, 2008; Comiso et al., 2008; Johannessen et al., 1999; Nuth et al., 2010; Steele et al., 2008; Polyakov et al., 2007; Zhang, 2005; Tremblay et al., 2011). The decrease of sea ice extent should result in an increase of the sea spray source area and thereby also in an increase of the sea spray emissions.

Nevertheless, there is not much known about the effects on sea spray emissions from changes in the physical properties of sea water in the Arctic Ocean region. A number of studies have examined the influence of water temperature, salinity, and oxygen saturation on particle number characteristics using artificial sea water, Baltic Sea water and North Atlantic sea water (Mårtensson et al., 2003; Russell and Singh, 2006; Tyree et al., 2007; Hultin et al., 2011, 2010). However, a comparison between the different studies is not straightforward due to different experimental setups and water origins. Zábori et al. (2012a) conducted, to our knowledge, the only systematic study so far combining physical properties of Arctic Ocean water (water temperature, salinity, oxygen saturation) with marine aerosol characteristics. One main finding of the Zábori et al. (2012a) study was that the marine particle number concentration decreased by at least four times with an increase in water temperature from $-1^{\circ} \mathrm{C}$ to about $6^{\circ} \mathrm{C}$. For higher water temperatures (upper measurement limit was $9^{\circ} \mathrm{C}$ ), the particle number concentration remained relatively constant. In this study we will examine if the trend found by Zábori et al. (2012a) is consistent with measurements conducted using Arctic Ocean water at higher water temperatures, sampled during summertime, despite an expected higher biological activity during the polar day period (Hodal et al., 2012). To this end, the dependency of the total particle number concentration and number size distribution on the water temperature, for the same temperature range, is compared for summer- and wintertime measurements. In addition, the dependency of the shape of the number size distribution on water temperature is examined for the different seasons.

\section{Experiments}

\subsection{Experimental site}

Laboratory experiments using Arctic Ocean sea water were carried out at $\mathrm{Ny}$-Ålesund $\left(78^{\circ} 55^{\prime} \mathrm{N}, 11^{\circ} 56^{\prime} \mathrm{E}\right)$, western Svalbard (Fig. 1a), in a marine laboratory during late Arctic summer conditions (from 24 August to 7 September 2009) and late Arctic winter conditions (from the 15 February to the 7 March 2010; cf. Zábori et al., 2012a). Sampling locations were selected to account for outer and inner fjord conditions, where the latter were influenced by glacial meltwater (Fig. 1b). During summertime, water outside the fjord mouth was sampled by boat, while the sampling took place from
Table 1. Meteorological average conditions, \pm standard deviations and minimum and maximum conditions during the water sampling period in summer (24 August to 7 September 2009) and winter (15 February to 7 March 2010). The values were measured in $\mathrm{Ny}$ Ålesund and provided by the Norwegian Meteorological Institute.

\begin{tabular}{|c|c|c|}
\hline & summer & winter \\
\hline avg. air temperature $\left({ }^{\circ} \mathrm{C}\right)$ & $3.2 \pm 1.7$ & $-14.4 \pm 4.1$ \\
\hline max. air temperature $\left({ }^{\circ} \mathrm{C}\right)$ & 8.2 & -1.7 \\
\hline min. air temperature $\left({ }^{\circ} \mathrm{C}\right)$ & -0.9 & -23.1 \\
\hline sum of precipitation $(\mathrm{mm})$ & 3.5 & 21.5 \\
\hline avg. air pressure (hPa) & $1008.9 \pm 11.4$ & $1015.9 \pm 13.9$ \\
\hline max. air pressure $(\mathrm{hPa})$ & 1022.0 & 1032.8 \\
\hline min. air pressure $(\mathrm{hPa})$ & 993.6 & 967.4 \\
\hline avg. wind direction $\left({ }^{\circ}\right)$ & $137.7 \pm 94.2$ & $156.0 \pm 54.2$ \\
\hline avg. wind speed $\left(\mathrm{m} \mathrm{s}^{-1}\right)$ & $1.5 \pm 1.6$ & $3.7 \pm 3.6$ \\
\hline max. wind speed $\left(\mathrm{m} \mathrm{s}^{-1}\right)$ & 7.4 & 19.9 \\
\hline min. wind speed $\left(\mathrm{m} \mathrm{s}^{-1}\right)$ & 0 & 0 \\
\hline avg. cloud cover (octas) & $5.4 \pm 2.9$ & $2.8 \pm 3.0$ \\
\hline max. cloud cover (octas) & 8 & 8 \\
\hline min. cloud cover (octas) & 0 & 0 \\
\hline
\end{tabular}

the coastline at the north-west side of the peninsula during winter conditions. In the inner part of Kongsfjorden, close to the glacier, water was sampled by boat during both seasons. In the laboratory, a deep water inlet is permanently installed. Thus, experiments with deep fjord water were also conducted during both campaigns. The deep water was pumped through a series of inline filters with pore sizes of $100 \mu \mathrm{m}$ and $20 \mu \mathrm{m}$ from a depth of $80 \mathrm{~m}$ and entered the lab after being treated with UV light. The mechanical filter and UV filter could not be bypassed. However, since the systems were not changed during the duration of the experiments, the potential effects of the filtration systems are assumed to be similar. In summer, water was additionally collected by boat north of $\mathrm{Ny}$ Alesund in the middle of the fjord (Fig. 1b). The waters sampled at the different locations are referred to as "water types". "Corresponding water types" are for both seasons referred to as (a) waters sampled outside the fjord mouth, (b) waters close to the glacier and (c) deep water. The meteorological conditions at the experimental site for the sampling period during summer and winter are summarized in Table 1.

\subsection{Factors influencing the environment within Kongsfjorden}

\subsubsection{External factors}

The two main external factors influencing the environment within Kongsfjorden are the atmospheric general circulation and the seasonality of available sunlight. High pressure systems over the Arctic Ocean and Greenland as well as 


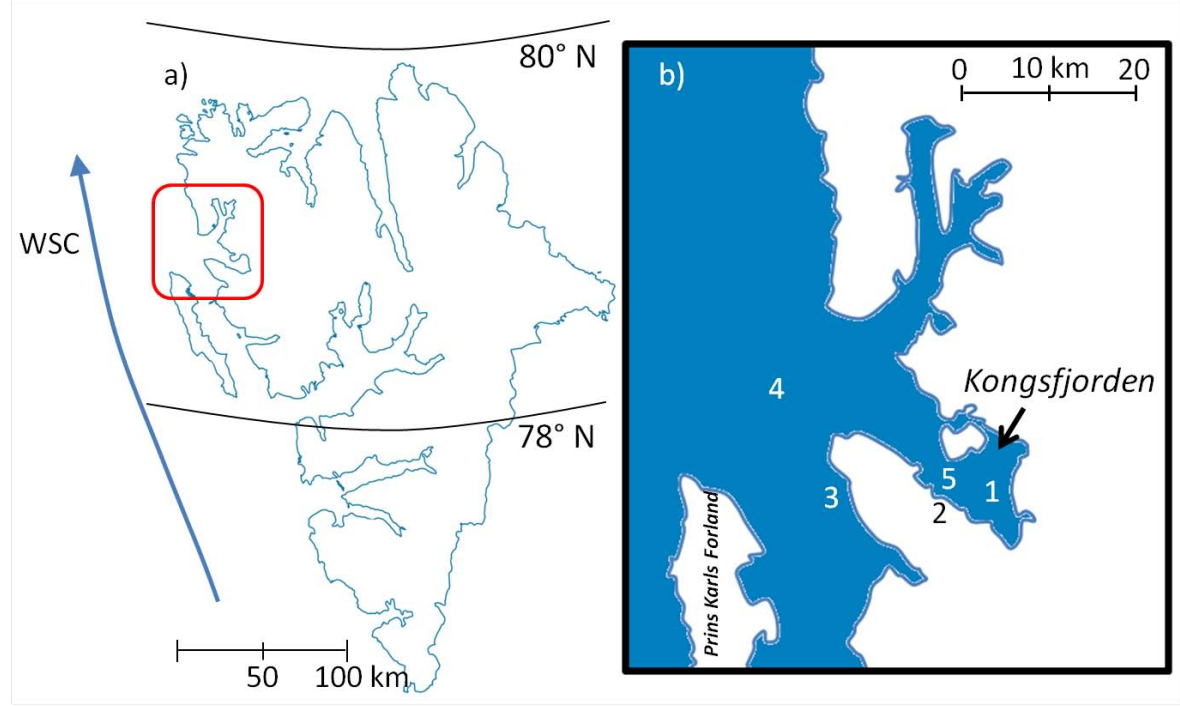

Fig. 1. (a) Overview map of the investigation area (marked red). Blue arrow indicates the direction of the West Spitsbergen Current (WSC). (b) Sampling locations. Point 1: close to the glacier Kongsbreen (summer and winter measurements); point 2: marine laboratory with deep sea water inlet in Ny-Ålesund (summer and winter measurements); point 3: outside of Kongsfjorden (winter measurements); point 4: outside of Kongsfjorden (summer measurements); point 5: middle of the fjord (summer measurements) (modified from Zábori et al., 2012a).

the Icelandic Low are the main atmospheric drivers for the weather patterns on Spitsbergen, which are generally characterized by northward advection of relatively warm and humid air from the North Atlantic (Svendsen et al., 2002).

The biology within Kongsfjorden is regulated by the availability of sunlight. The polar day period (18 April to $23 \mathrm{Au}-$ gust) promotes phytoplankton productivity during the summer months, while during polar night (25 October to 17 February) the productivity is inhibited (Svendsen et al., 2002; Hop et al., 2002; Hodal et al., 2012). A spring bloom, peaking in May, has been reported to be the only predictable bloom in Kongsfjorden, while blooms during summer occur irregularly (Hodal et al., 2012; Hop et al., 2006, 2002).

\subsubsection{Internal factors}

Phytoplankton production within Kongsfjorden is also regulated by internal factors. High concentrations of sediments result from increasing river discharge and ice melt during summer and decrease the transparency of the water, especially in the inner part of the fjord, thereby limiting phytoplankton growth (Hop et al., 2002; Svendsen et al., 2002). Contrastingly, in the outer parts of the fjord phytoplankton growth is limited by grazing during the summer months (Hop et al., 2002).

Two main water masses normally flow northwards along the west coast of Spitsbergen. The West Spitsbergen Current (WSC) transports relatively warm and saline Atlantic water $\left(T_{\mathrm{w}}>3{ }^{\circ} \mathrm{C}\right.$, salinity $\left.>34.9 \mathrm{psu}\right)$ and mixes with the cooler and fresher Arctic water $\left(-1.5^{\circ} \mathrm{C}<T_{\mathrm{w}}<1.0^{\circ} \mathrm{C}\right.$, $34.30 \mathrm{psu}<$ salinity $<34.80 \mathrm{psu})$ on the western shelf of
Spitsbergen (Piehl Harms et al., 2007; Svendsen et al., 2002). The predominance of these water masses changes during the year. During autumn and winter, the Arctic water mass generally dominates, while the Atlantic water is more prevalent during summer months (Hop et al., 2006). In Kongsfjorden, the water masses are further modified by inflow of fresh waters from rivers and glaciers during summer and by surface cooling and ice formation during winter (Piehl Harms et al., 2007).

The climate of the west coast of Spitsbergen is influenced by the large amount of heat which is transported northwards by the WSC. This leads to a mostly ice-free ocean along the west coast of Svalbard and to relatively mild air temperatures compared to other locations at a similar latitude. The mean air temperature at Ny-Ålesund from 1961 to 1990 was $\sim-15^{\circ} \mathrm{C}$ in February and $\sim 4{ }^{\circ} \mathrm{C}$ in July (Svendsen et al., 2002). The average annual sea water temperature in Kongsfjorden has been estimated to be slightly above $0^{\circ} \mathrm{C}$, and sea ice formation in winter is most pronounced close to the coast and in the inner parts of the fjord (Ito and Kudoh, 1997; Svendsen et al., 2002).

\subsection{Experimental setup}

The experimental setup was similar for the summer and winter experiments (cf. Zábori et al., 2012a for winter experiments). Nevertheless some differences in water flow and dilution rate by clean air occurred. Collected sea water was poured into a $190 \mathrm{~L}$ stainless steel storage tank situated in the laboratory. From the steel tank the water was pumped into a carefully sealed polyethylene bottle (Nalgene Labware) 


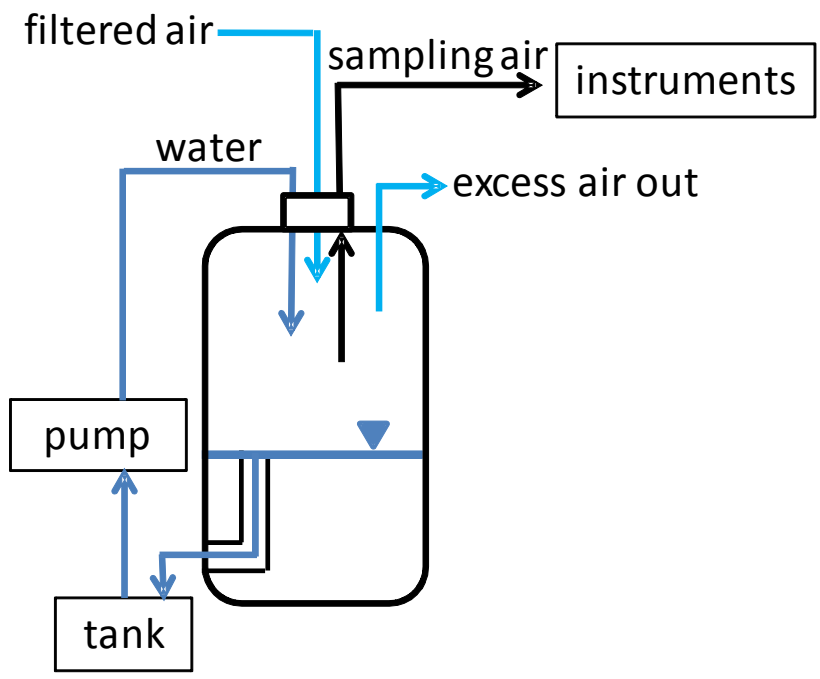

Fig. 2. A schematic picture of the bubble bursting experimental setup (Zábori et al., 2012a). The tank was used as a buffer to recirculate the sea water sample trough the PET bottle, where sea spray aerosols were produced by an impinging water jet. Darker blue lines represent water, and the triangle symbol indicates the water surface in the bottle.

using an aquarium centrifugal pump (EHEIM) at a rate of 2.2 $\mathrm{Lmin}^{-1}$ during the summer experiments and at a rate of $4.8 \mathrm{~L} \mathrm{~min}^{-1}$ during the winter experiments. Different positions of the pump during different seasons caused the different pumping rates. The water entered the bottle through a stainless steel nozzle with an inner diameter of $5 \mathrm{~mm}$ producing a water jet mimicking a wave crest, which entrains air into sea water. The air subsequently breaks up into bubbles, which burst at the water surface. The distance between the nozzle exit and the water surface was approximately $16 \mathrm{~cm}$ (for both the winter and summer experiments). The water level in the polyethylene (PET) bottle was kept stable by a simple overflow system, and the water volume remained constant at $10 \mathrm{~L}$. Water flowing from the PET bottle was transferred back to the buffer storage tank through a PVC tube (more details about the experimental procedure can be found in Sect. 2.5).

Fuentes et al. (2010a) compared different mechanisms for marine aerosol production in laboratory experiments with respect to their ability to reproduce a realistic oceanic bubble size spectrum. It was concluded that a plunging water jet was the best method for reproducing the shape of an oceanic bubble size spectra (cf. also Hultin et al., 2010). Hence, it is assumed that this method also results in the most realistic bubble-mediated aerosol size spectra (i.e. neglecting spume droplets produced from the tearing of breaking waves).

To avoid any contamination by room air, air was pumped through an ultra filter (type $\mathrm{H}$ cartridge, MSA, Pittsburgh) resulting in particle-free air into the PET bottle. The flow rate was $9 \mathrm{~L} \mathrm{~min}^{-1}$ for summer experiments and $12 \mathrm{~L} \mathrm{~min}^{-1}$ for winter experiments, respectively. Excess air was allowed to freely leave the top of the PET bottle through an opening of $5 \mathrm{~mm}$ in diameter. The quality of the particle-free air and the integrity of the whole setup were regularly checked by switching off the water jet. The sample air was collected from an air volume above the sea water in the PET bottle. The total sampling air flow was kept stable at $7.2 \mathrm{~L} \mathrm{~min}^{-1}$ (summer) and at $5.0 \mathrm{~L} \mathrm{~min}^{-1}$ (winter) during all experiments. A schematic of the experimental setup is shown in Fig. 2.

\subsection{Instrumentation}

Air sampling from the PET bottle was conducted through a $2 \mathrm{~m}$ long $1 / 4^{\prime \prime}$ stainless steel tube to the instrumental payload. Based on the geometry of the aerosol sampling lines and associated inertial losses, the largest particles reliably detected were estimated to be around $5 \mu \mathrm{m}$ in diameter $\left(D_{p}\right)$. The total aerosol number concentration was measured at $1 \mathrm{~Hz}$ for particles with a $D_{p}>0.01 \mu \mathrm{m}$ using a TSI model 3010 condensation particle counter (CPC) and for particles with a $D_{p}>0.25 \mu \mathrm{m}$ using a GRIMM 1.109 optical particle counter (OPC).

The size distribution for the size range $0.01 \mu \mathrm{m}<D_{p}<$ $0.30 \mu \mathrm{m}$ was determined using a closed-loop sheath air custom-built differential mobility particle sizer (DMPS) equipped with a TSI 3010 CPC. One scan covering 15 size bins was completed in $2.5 \mathrm{~min}$. The aerosol size distribution in the range $0.25<D_{p}<32 \mu \mathrm{m}$ was determined every $6 \mathrm{~s}$ with a GRIMM 1.109 optical particle counter (OPC), sizing particles in 31 bins. The relative humidity of the sampled air was monitored in the sampling line prior to entering individual instruments with a Hygroclip SC04 hygrometer (Rotronic). The relative humidity during the experiments was lower than $30 \%$ (winter and summer). Hence, we can safely assume that the observations were representative for dry diameter aerosol particles.

Water temperature, salinity and oxygen saturation were continuously measured in the steel tank with a Stratos 2402 Cond and a Stratos 2402 Oxy from the Knick Elektronische Messgeräte $\mathrm{GmbH} \& \mathrm{Co}$.

\subsection{Experimental procedure and data analysis}

The sampled water from the different locations (cf. Sect. 2.1) was split up in two parts to be used in two experiments for each water type (in the range from $55 \mathrm{~L}$ to $140 \mathrm{~L}$ for each individual experiment). In summer, the two experiments with the same type of water were conducted the same day, except for one case when the second sample was stored until the following day. In the winter, half of the samples were stored in a dark room at $4{ }^{\circ} \mathrm{C}$ to be used for experiments on the consecutive day. The reason for this difference in procedure was that during wintertime field sampling was more timeconsuming and it was not possible to conduct more than one experiment per day. 
After the water samples were poured into the storage tank and the PET bottle, the water temperature increased due to the exposure to room temperature. Warming rates during both summer- and wintertime experiments were both on average between $1{ }^{\circ} \mathrm{Ch}^{-1}$ and $2{ }^{\circ} \mathrm{Ch}^{-1}$. While water temperatures covered the range between $-2^{\circ} \mathrm{C}$ and $10^{\circ} \mathrm{C}$ during the winter experiments, water temperatures were between $5^{\circ} \mathrm{C}$ and $16^{\circ} \mathrm{C}$ during the summer experiments.

The analysis strategy was as follows: (1) based on corresponding water types, to compare the total particle number concentrations for the summer and winter data as a function of water temperature with a focus on the overlapping $T_{\mathrm{w}}$ ranges between the two seasons; (2) to compare the whole particle number size distribution (i.e. the shape and particle number concentration for different size intervals) for corresponding water types and temperature ranges for both the summer and winter data; (3) to compare separately for winter and summer data the particle number size distribution shape for each water type and its dependency on water temperature.

The particle number concentrations were adjusted for different dilution rates of the aerosol sample by clean particlefree air. That is, observed concentrations are normalized to the relative amount of particle-free air introduced to the vessel compared to the sample air flow. For a comparison of the winter and summer total particle number concentration data, total particle number concentration medians were calculated for $1^{\circ} \mathrm{C}$ temperature bins for each different water type.

To compare summer and winter particle number size distributions, median number size distributions were calculated for overlapping $T_{\mathrm{w}}$ ranges for the different water types. Median particle number size distributions were calculated for overlapping temperature ranges: $6-7^{\circ} \mathrm{C}$ for deep fjord water, $5-10^{\circ} \mathrm{C}$ for close to glacier water, and $6-10^{\circ} \mathrm{C}$ for fjord mouth water. For all size distributions, the medians are based on total experiment measurement times ranging between about $76 \mathrm{~min}$ and $5 \mathrm{~h} 10 \mathrm{~min}$, except for the winter size distribution outside the fjord mouth for the $T_{\mathrm{w}}$ range $7-8^{\circ} \mathrm{C}$, where the total measurement time was only $10 \mathrm{~min}$.

To emphasize differences in the dependency of the shape of the aerosol size distributions on water temperature, each median distribution was normalized to its integral number density. The shape comparisons were made separately for summer and winter measurements, respectively. The total average measurement time for which the medians of the size distributions are based on is $2 \mathrm{~h} 13 \mathrm{~min}$, with $5 \mathrm{~min}$ as the shortest measurement time and $6 \mathrm{~h} 52 \mathrm{~min}$ as the longest. The large variation in total measurement times is explained by the different numbers of repeating experiments for different water types. In addition, it should be mentioned that the repeating experiments did not always cover exactly the same water temperature range.

The first two OPC bins were not used in the analysis of the winter data, or subsequent calculations, but are presented for completeness. There is evidence that, for the overlapping size range of the DMPS and OPC instruments, the DMPS measurements provide higher quality data. Including the first two channels of the OPC led to an overestimation of the total particle number, when integrating over the whole particle number size distribution.

\section{Results}

\subsection{Comparison of total particle number concentrations from summer and winter measurements}

Median particle number concentrations for both $D_{p}>$ $0.01 \mu \mathrm{m}$ and $D_{p}>0.25 \mu \mathrm{m}$ as a function of water temperature were compared for summer and winter measurements for the three different sampling locations (Fig. 3a-c). In addition, the dependency of the resulting ratio between particles $D_{p}>0.01 \mu \mathrm{m}$ and $D_{p}>0.25 \mu \mathrm{m}$ on water temperature was compared for summer and winter conditions (Fig. 3d). Three patterns can be observed: (i) particle number concentrations decrease with increasing $T_{\mathrm{w}}$ up to a water temperature of about $5-7^{\circ} \mathrm{C}$ (a factor of $4-5$ decrease from about $1^{\circ} \mathrm{C}$ to $6^{\circ} \mathrm{C}$ for all different water types and $D_{p}>0.01 \mu \mathrm{m}$ ) and stay relatively constant for higher water temperatures (in accordance with Zábori et al., 2012a); (ii) in general, no distinct concentration shift for particles with $D_{p}>0.01 \mu \mathrm{m}$ between the summer and winter measurements can be observed in the overlapping temperature bins; (iii) for overlapping water temperature ranges, summer measurements show on average a ratio of three and winter measurements a ratio of two for particle concentrations of $D_{p}>0.01 \mu \mathrm{m} / D_{p}>0.25 \mu \mathrm{m}$.

Even if the dependency of particle number concentrations on water temperature is consistent for winter and summer measurements, summer particle number concentrations for $D_{p}>0.01 \mu \mathrm{m}$ are about 2-3 times higher than the particle number concentrations recorded during winter for the lowest overlapping temperature bin $\left(T_{\mathrm{w}}\right.$ between $5^{\circ} \mathrm{C}$ and $\left.6^{\circ} \mathrm{C}\right)$. This is observed for water sampled close to the glacier and at the fjord mouth. The uncertainty range (between the 75th percentiles and 25th percentiles of the data) of particle number concentrations for water sampled close to the glacier is between 1593 and 622 particles $\mathrm{cm}^{-3}$ during summertime and between 662 and 417 particles $\mathrm{cm}^{-3}$ during wintertime for a median water temperature between 5 and $6^{\circ} \mathrm{C}$ (cf. Fig. 3b). The same uncertainty range of particle number concentrations of water sampled at the fjord mouth is between 1119 and 675 particles $\mathrm{cm}^{-3}$ for water sampled during summertime and between 661 and 521 particles $\mathrm{cm}^{-3}$ for water sampled during wintertime for median water temperatures between 5 and $6^{\circ} \mathrm{C}$ (cf. Fig. 3c).

The observed decrease in particle number concentrations with increasing water temperatures up to about $5-7^{\circ} \mathrm{C}$ (cf. Fig. 3a-c) is a result of a decrease in particle emissions rather than a result of particle dynamics as shown in Zábori et al. (2012a). 

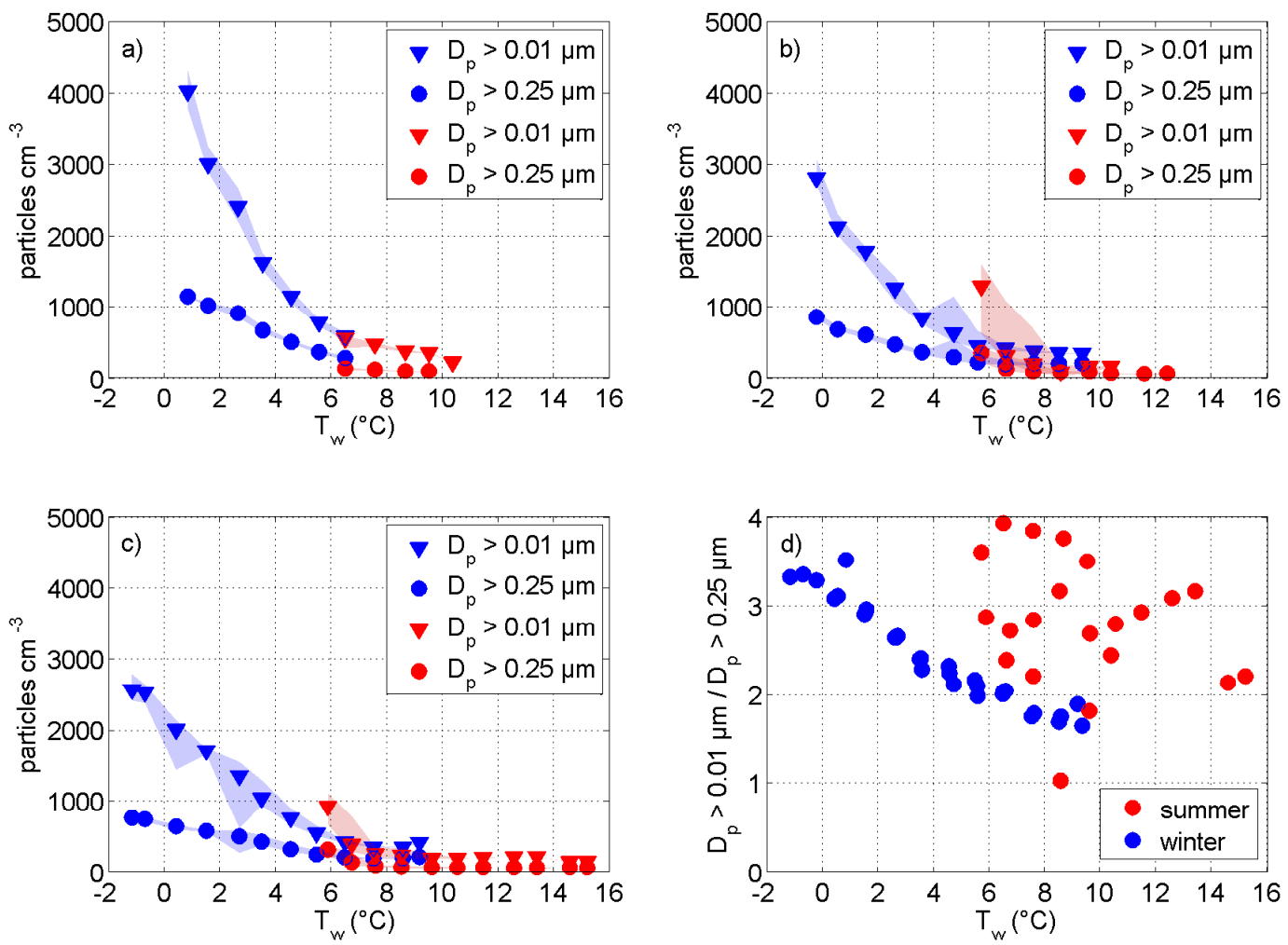

Fig. 3. The median particle number concentrations as a function of water temperature $\left(T_{\mathrm{W}}\right)$. Blue data points represent winter data and red data points summer data with triangles for particles $D_{p}>0.01 \mu \mathrm{m}$ and circles for particles with $D_{p}>0.25 \mu \mathrm{m}$. Blue and red shaded areas represent the interquartile ranges. Particle number concentrations are the result of bubble bursting in (a) deep fjord water, (b) water sampled close to glacier, (c) water sampled at the fjord mouth and (d) the ratio between particle number concentration of particles $D_{p}>0.01 \mu \mathrm{m}$ and $D_{p}>0.25 \mu \mathrm{m}$. The ratios were built for each data point pair shown in (a-c).
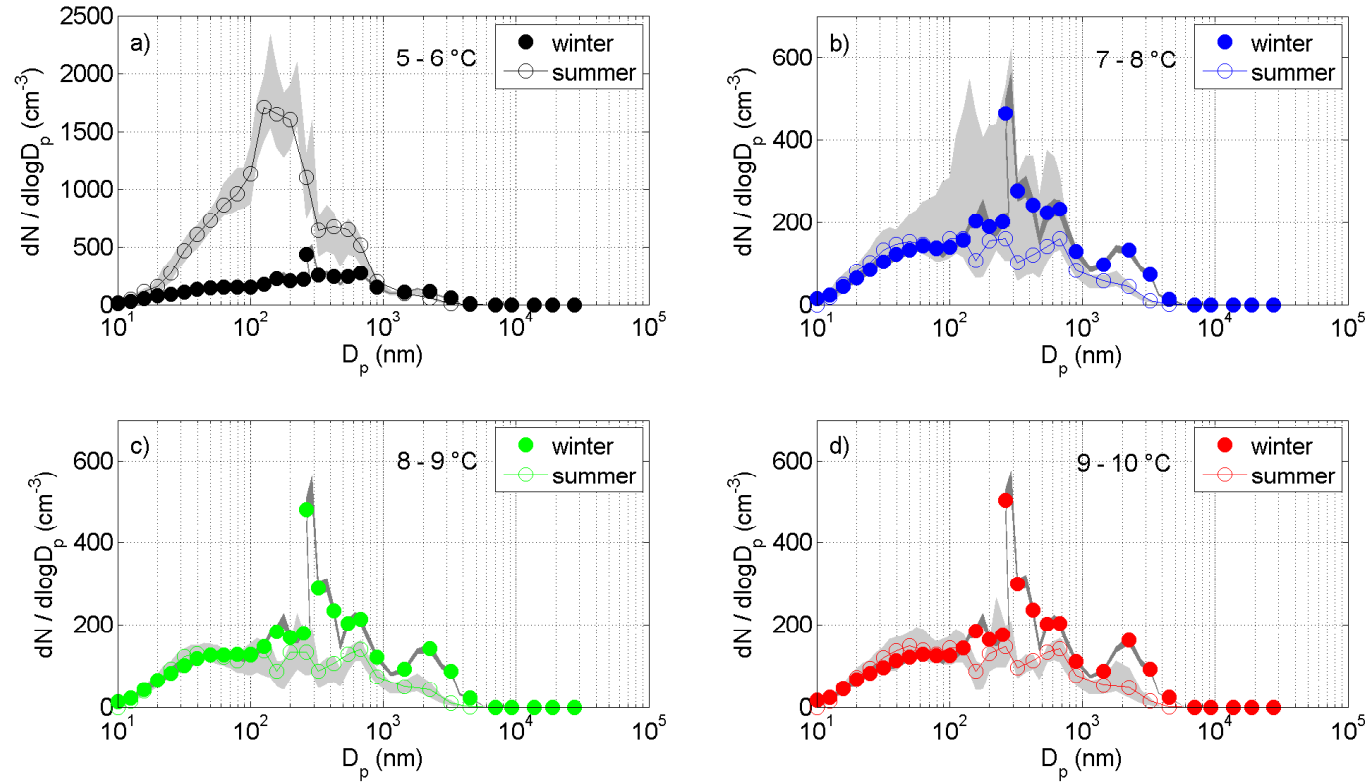

Fig. 4. Comparison of particle number size distributions resulting from water sampled close to the glacier during summertime and wintertime, for the same water temperature ranges of (a) $5-6{ }^{\circ} \mathrm{C}$, (b) $7-8{ }^{\circ} \mathrm{C}$, (c) $8-9{ }^{\circ} \mathrm{C}$ and (d) $9-10^{\circ} \mathrm{C}$. For clarity only every second data point is shown. Grey shaded areas represent the interquartile ranges. Note the different scale for the lowest temperature range. 

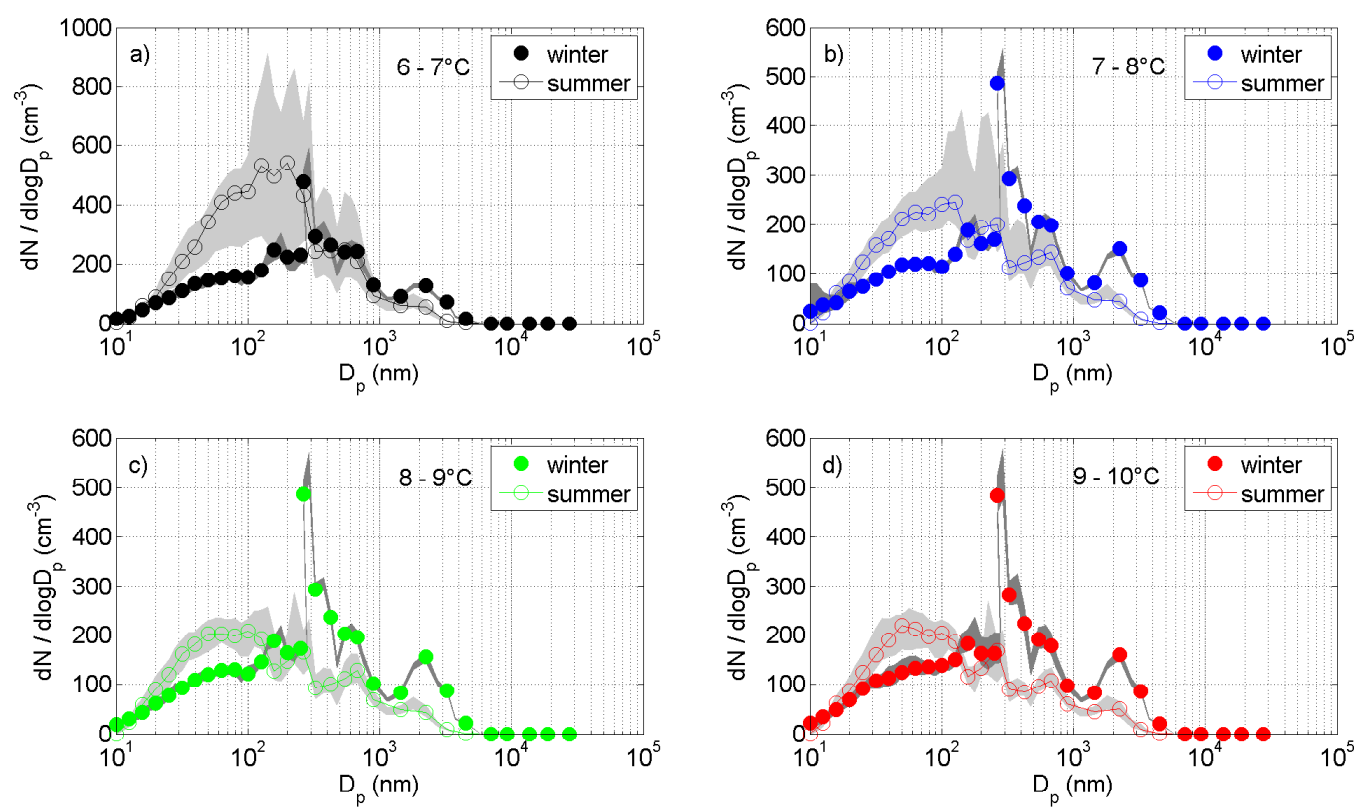

Fig. 5. Comparison of particle number size distributions resulting from water sampled close to the fjord mouth during summertime and wintertime, for the same water temperature ranges of (a) $6-7{ }^{\circ} \mathrm{C}$, (b) $7-8{ }^{\circ} \mathrm{C}$, (c) $8-9^{\circ} \mathrm{C}$ and (d) $9-10^{\circ} \mathrm{C}$. For clarity only every second data point is shown. Grey shaded areas represent the interquartile ranges. Note the different scale for the lowest temperature range.

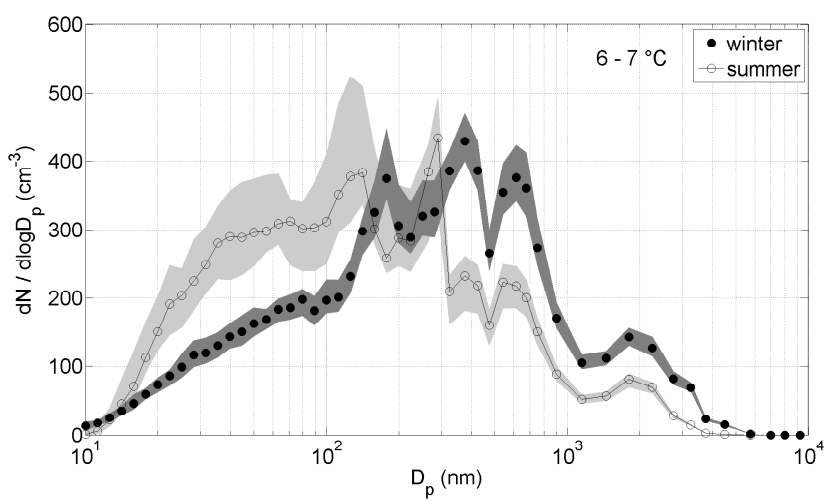

Fig. 6. Comparison of particle number size distributions resulting from deep sea water during summertime and wintertime, for the same water temperature ranges of $6-7^{\circ} \mathrm{C}$. Grey shaded areas represent the interquartile ranges.

\subsection{Particle number size distributions from summer and winter measurements}

Particle number size distributions based on Arctic summer and Arctic winter measurements are compared for overlapping water temperature ranges for different water types (Figs. 4-6). A two-sample Kolmogorov-Smirnov test, at a $95 \%$ confidence level, was applied to all data to test the significance of any differences between the size distributions. Additionally, the relative differences in total particle number concentrations for $D_{p}<0.125 \mu \mathrm{m}$ and $D_{p}>0.125 \mu \mathrm{m}$ are compared between summer and winter measurements.
The division into these sizes was made as the relationship between summer and winter data seems to change at about $D_{p} 0.125 \mu \mathrm{m}$.

Figure 4 shows median number size distributions resulting from water sampled close to the glacier. For the lowest overlapping $T_{\mathrm{w}}$ range between $5^{\circ} \mathrm{C}$ and $6^{\circ} \mathrm{C}$, significantly higher particle number concentrations for $D_{p}$ from about $0.02 \mu \mathrm{m}$ to $0.700 \mu \mathrm{m}$ were observed for water sampled during summer conditions (Fig. 4a). For larger and smaller sizes within the $T_{\mathrm{w}}$ range of $5-6^{\circ} \mathrm{C}$, the particle number concentrations do not differ significantly.

Figure $4 \mathrm{~b}$ compares median number size distributions of summer and winter measurements for $T_{\mathrm{w}}$ between $7^{\circ} \mathrm{C}$ and $8^{\circ} \mathrm{C}$. No significant differences in concentrations between the summer and winter experiments occurred for particle sizes $D_{p}<0.025 \mu \mathrm{m}$. Up to about $D_{p} 0.125 \mu \mathrm{m}$, significantly higher particle number concentrations for the summertime conditions are found compared to concentrations during wintertime, although the median concentrations do not differ much (difference of about $3 \%$ ). For sizes $D_{p}>0.125 \mu \mathrm{m}$, winter concentrations are generally significantly higher than summer concentrations, except for the size range between $D_{p} 0.265$ and $D_{p} 0.750 \mu \mathrm{m}$. Generally, particle number concentrations are comparable for winter and summer measurements for $D_{p}<0.125 \mu \mathrm{m}$ and are about $50 \%$ higher for the winter measurements for $D_{p}>0.125 \mu \mathrm{m}$.

Figure $4 \mathrm{c}$ displays summer and winter size distributions resulting from waters having a $T_{\mathrm{w}}$ between $8{ }^{\circ} \mathrm{C}$ and $9^{\circ} \mathrm{C}$. Particle number concentrations do not differ significantly for $D_{p}<0.015 \mu \mathrm{m}$ between summer and winter measurements. 
Significantly higher concentrations during summertime occur for the size range $D_{p} 0.015-0.060 \mu \mathrm{m}$. Winter concentrations are generally significantly higher than summer concentrations for particles with $D_{p}>0.060 \mu \mathrm{m}$. Particle number concentrations are for $D_{p}<0.125 \mu \mathrm{m}$ about $20 \%$ higher for summer than winter measurements and for $D_{p}>0.125 \mu \mathrm{m}$ about $40 \%$ lower for summer compared to winter.

Figure $4 \mathrm{~d}$ presents size distributions of both seasons resulting from $9^{\circ} \mathrm{C}$ to $10^{\circ} \mathrm{C}$ warm water. No significantly different particle number concentrations between summer and winter measurements for the smallest particle sizes $\left(D_{p}<\right.$ $0.025 \mu \mathrm{m}$ ) were detected. Up to about a $D_{p}$ of $0.100 \mu \mathrm{m}$, significantly higher particle number concentrations for the summertime conditions are found compared to concentrations during wintertime. Generally, particle sizes larger than a $D_{p}$ of $0.100 \mu \mathrm{m}$ show significantly higher winter concentrations than summer concentrations. Particle number concentrations for $D_{p}<0.125 \mu \mathrm{m}$ are comparable for summer and winter measurements (difference of about $2 \%$ ) and for $D_{p}>0.125 \mu \mathrm{m}$ about $50 \%$ lower for summer compared to winter measurements.

Figure 5 compares median number size distributions of summer and winter measurements resulting from water sampled at the fjord mouth for overlapping $T_{\mathrm{w}}$ ranges. Figure 5a shows summer and winter particle number concentrations for water temperatures between $6^{\circ} \mathrm{C}$ and $7^{\circ} \mathrm{C}$. Summer particle number concentrations are significantly higher than winter particle number concentrations for sizes between $D_{p}$ $0.015 \mu \mathrm{m}$ and $0.223 \mu \mathrm{m}$. The winter particle number concentration is significantly higher for sizes between $1.450 \mu \mathrm{m}$ and $5 \mu \mathrm{m}$. Particle number concentrations of the other measured sizes are not significantly different between summer and winter measurements.

Figure $5 \mathrm{~b}$ presents median particle number concentrations of summer and winter measurements for the water temperature range $7-8^{\circ} \mathrm{C}$. Summer particle number concentrations are significantly higher for $D_{p} 0.02-0.140 \mu \mathrm{m}$ and for $D_{p}$ $0.200-0.223 \mu \mathrm{m}$. The winter particle number concentrations are significantly higher than the summer particle number concentrations for $D_{p} 0.265-0.425 \mu \mathrm{m}$ and for $D_{p} 0.625-$ $5.0 \mu \mathrm{m}$. Particle number concentrations of the other measured sizes are not significantly different between summer and winter measurements. Particle number concentrations are for $D_{p}<0.125 \mu \mathrm{m}$ about $70 \%$ higher for summer than winter measurements and for $D_{p}>0.125 \mu \mathrm{m}$ about $30 \%$ lower for summer compared to winter.

Figure 5c displays a comparison between winter and summer particle number concentrations for water temperatures between $8^{\circ} \mathrm{C}$ and $9^{\circ} \mathrm{C}$. Summer particle number concentrations are significantly higher for sizes between $D_{p} 0.014 \mu \mathrm{m}$ and $0.125 \mu \mathrm{m}$, and winter particle number concentrations are higher for the size ranges $D_{p} 0.010-0.0125 \mu \mathrm{m}, D_{p} 0.158$ $0.177 \mu \mathrm{m}$ and for $0.265-5 \mu \mathrm{m}$. Particle number concentrations of the other measured sizes are not significantly different between summer and winter measurements. Particle number concentrations are for $D_{p}<0.125 \mu \mathrm{m}$ about $55 \%$ higher for summer than winter measurements and for $D_{p}>$ $0.125 \mu \mathrm{m}$ about $40 \%$ lower for summer compared to winter.

Figure 5d compares summer- and wintertime measurements of particle number size distributions for water temperatures between $9{ }^{\circ} \mathrm{C}$ and $10^{\circ} \mathrm{C}$. It is illustrated that particle number concentrations for the size range $D_{p} 0.016-0.125 \mu \mathrm{m}$ are significantly higher for the summer measurements compared to the winter measurements. Particle number concentrations for the size ranges between $D_{p} 0.010-0.012 \mu \mathrm{m}$, between $D_{p} 0.141-0.200 \mu \mathrm{m}$ and between $D_{p} 0.265-5 \mu \mathrm{m}$ are significantly larger for winter measurements compared to summer measurements. Particle number concentrations are about $46 \%$ higher for $D_{p}<0.125 \mu \mathrm{m}$ during summer than winter measurements, and for $D_{p}>0.125 \mu \mathrm{m}$ about $45 \%$ lower for summer compared to winter measurements.

Figure 6 shows particle number size distributions based on experiments with deep water for summer- and wintertime, for the only common water temperature range of $6-7^{\circ} \mathrm{C}$. Both size distributions overlap for $D_{p}$ between approximately 10 and $20 \mathrm{~nm}$ and for the size range $D_{p} 0.125-0.300 \mu \mathrm{m}$, which is supported by the significance test. Between $D_{p} 0.020 \mu \mathrm{m}$ and $0.125 \mu \mathrm{m}$, the particle number concentration based on summer measurements exceeds significantly the one based on winter measurements, while for $D_{p}>0.300 \mu \mathrm{m}$ the opposite result is obtained.

In order to characterize the particle number size distributions, log-normal functions were fitted to the median particle number size distributions of the summer and winter data presented in Fig. 4 and Fig. 5. When calculating the medians for the respective season, the lowest water temperature range for the water sampled close to the glacier and the water sampled close to the fjord mouth were not considered (cf. Sect. 4). The parameters of the fitted log-normal distributions are presented in Table 2.

Median volume size distributions for the data presented in Figs. 4-6 are shown in Figs. 7-9. The maxima of the volume distribution occur at dry diameters between 3 and $4 \mu \mathrm{m}$ for the winter measurements and between 2 and $3 \mu \mathrm{m}$ for the summer measurements. The volume size distribution changes in a similar manner to the particle number size distribution, even though the differences between winter and summer are more distinct for the larger particles when comparing volume due to the size dependence of the volume calculations.

The normalized dependencies of the particle number size distributions on water temperature are presented in Figs. 10 and 11 for summer and winter conditions, respectively. The experiments with deep sea water cover the smallest $T_{\mathrm{w}}$ range during summer measurements $\left(6-10^{\circ} \mathrm{C}\right)$ and result in normalized median number size distributions with similar shape for all individual $T_{\mathrm{w}}$ ranges (Fig. 10a). Experiments conducted with water sampled close to the glacier, sampled at the fjord mouth and sampled at the middle of the fjord (Fig. 10bd) show a decrease of the relative particle density in the 

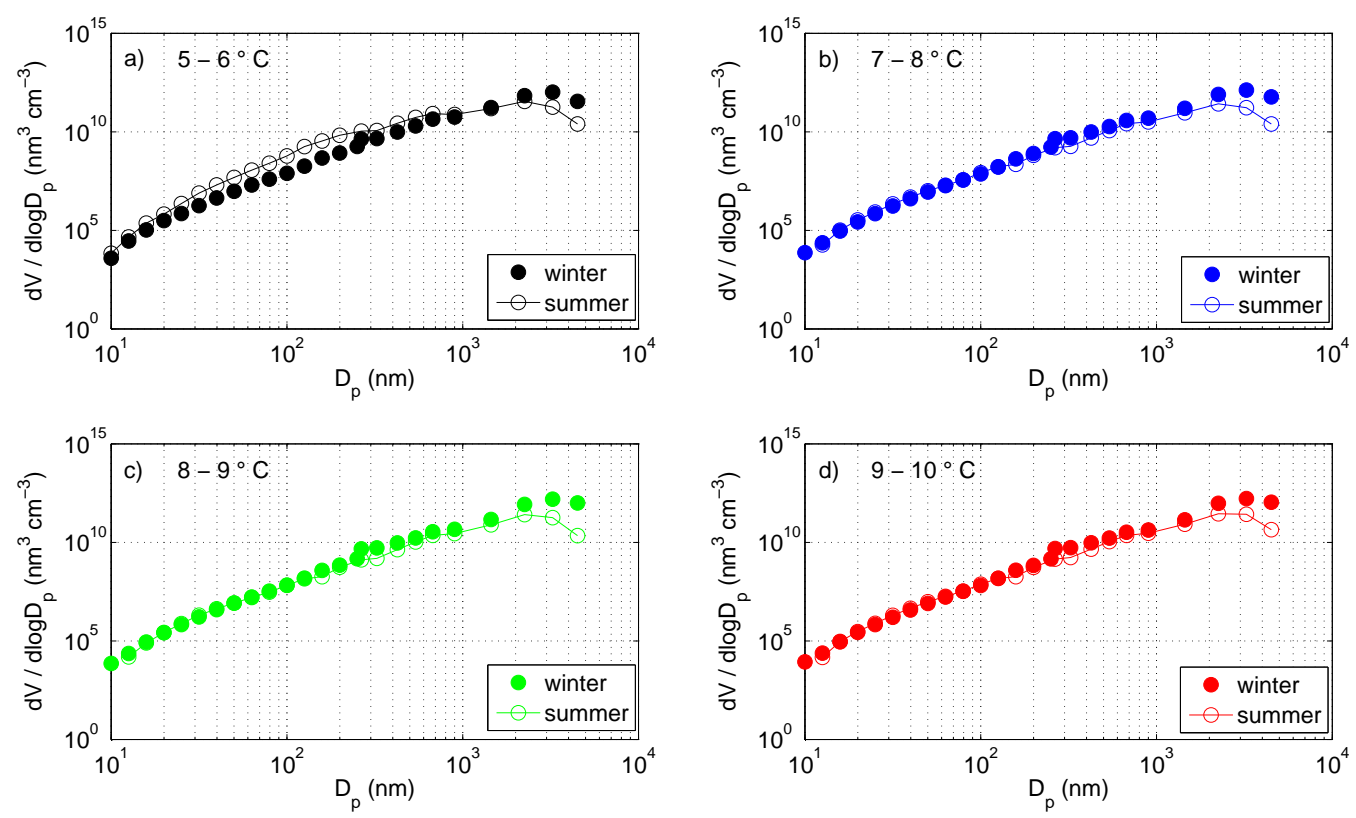

Fig. 7. Comparison of particle volume size distributions resulting from water sampled close to the glacier during summertime and wintertime, for the same water temperature ranges of (a) $5-6^{\circ} \mathrm{C}$, (b) $7-8{ }^{\circ} \mathrm{C}$, (c) $8-9^{\circ} \mathrm{C}$ and (d) $9-10^{\circ} \mathrm{C}$. For clarity only every second data point is shown.
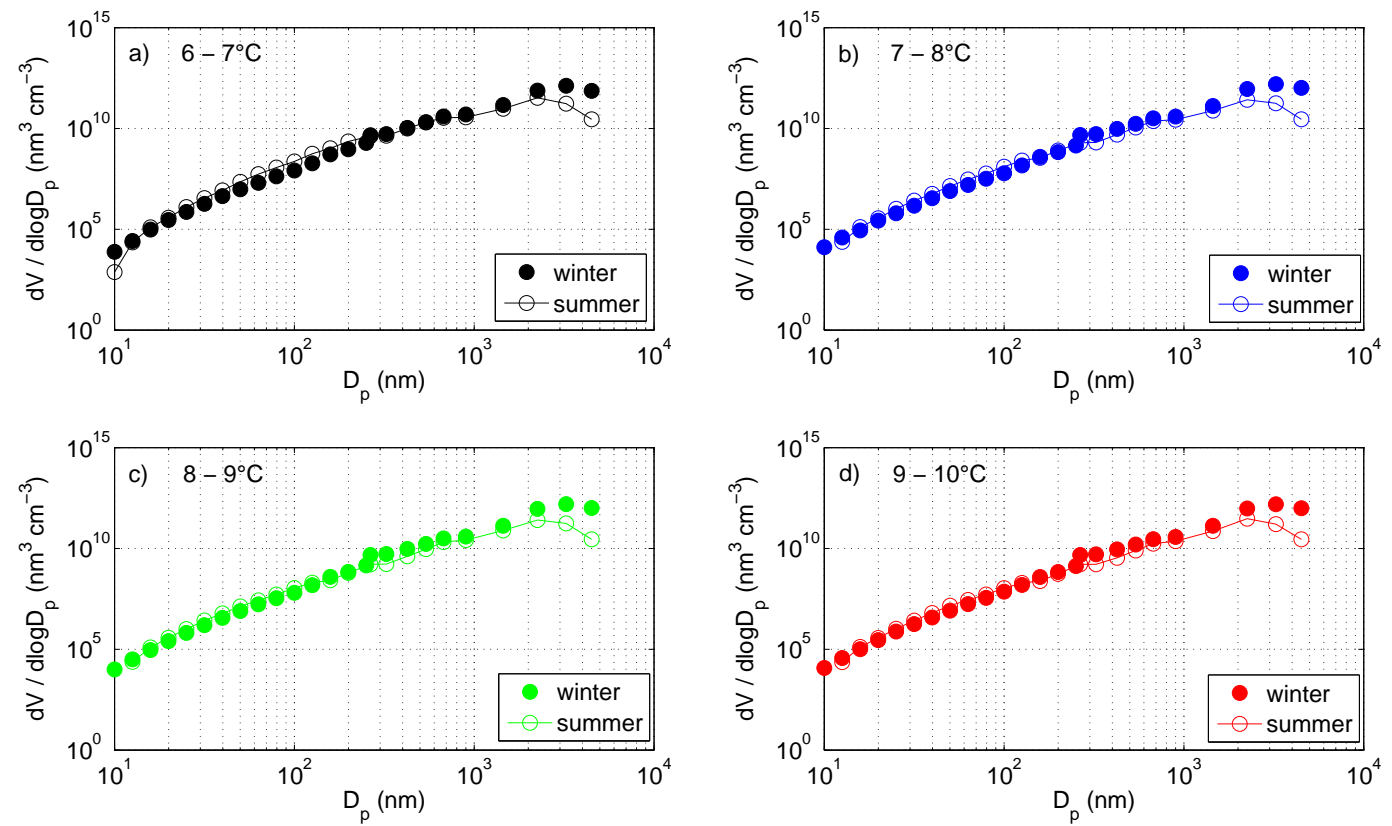

Fig. 8. Comparison of particle volume size distributions resulting from water sampled close to the fjord mouth during summertime and wintertime, for the same water temperature ranges of (a) $6-7{ }^{\circ} \mathrm{C}$, (b) $7-8^{\circ} \mathrm{C}$, (c) $8-9^{\circ} \mathrm{C}$ and (d) $9-10^{\circ} \mathrm{C}$. For clarity only every second data point is shown.

accumulation mode and a shift towards smaller sizes (with a local maximum at about $D_{p} 0.05 \mu \mathrm{m}$ ) with increasing $T_{\mathrm{w}}$ from about $5-7^{\circ} \mathrm{C}$ to about $10-15^{\circ} \mathrm{C}$. A different pattern is observed for the normalized particle number concentrations based on winter measurements (Fig. 11a-c). For the accu- mulation mode, the relative particle number concentration is indeed decreasing with increasing water temperature (from about $-1-3{ }^{\circ} \mathrm{C}$ to about $6-10^{\circ} \mathrm{C}$ ) for a part of the size range $\left(D_{p} 0.100-0.300 \mu \mathrm{m}\right)$, but at the same time an increase in 


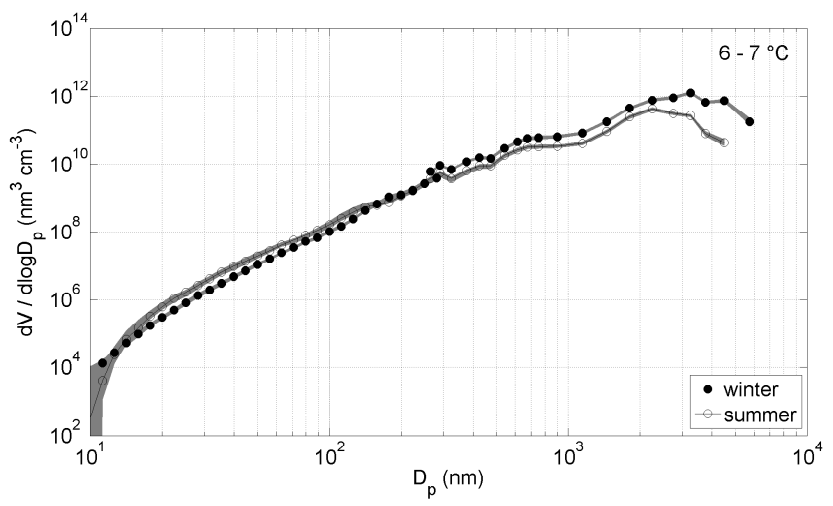

Fig. 9. Comparison of particle volume size distributions resulting from deep sea water during summertime and wintertime, for the same water temperature ranges of $6-7^{\circ} \mathrm{C}$. Grey shaded areas represent the interquartile ranges.

the relative particle number concentration for particles with $D_{p}>1 \mu \mathrm{m}$ is observed for all water types.

\section{Discussion}

Despite the aim to reproduce the technical conditions of the summertime measurements during the wintertime campaign, differences in the dilution rate of the aerosol samples by clean air and the water pump rate could not be avoided. Whereas data could be adjusted for the different dilution factors, it was not possible to correct for the different water flow rates. It cannot be excluded that different water flows during summer and winter experiments led to different aerosol characteristics. Fuentes et al. (2010a) examined the bubble spectra generated by a plunging-water jet system, as a function of water recirculation rate. Especially for the larger bubbles, differences for different water flow rates occurred. These larger bubbles in the water (bubble diameter $>1-2 \mathrm{~mm}$ ) are important for the film drop production, meaning submicron aerosol production. However, a comparison of normalized particle number size distributions caused by a water pumping rate of $3 \mathrm{~L} \mathrm{~min}^{-1}$ and $4.8 \mathrm{~L} \mathrm{~min}^{-1}$ showed no appreciable differences. Nevertheless, it cannot be excluded that differences in shape do not occur when comparing particle number size distributions caused by pumping rates of $2.2 \mathrm{~L} \mathrm{~min}^{-1}$ (summer measurements) and $4.8 \mathrm{~L} \mathrm{~min}^{-1}$ (winter measurements). Despite the different water flow rates during the seasons, the results show a consistent particle number concentration for overlapping $T_{\mathrm{w}}$ ranges for the summer and winter measurements (Fig. 3a-c). This tends to support the presumption that differences in water flow rates within our experiments do not contribute significantly to the observed pattern during either season. Differences of up to more than $50 \%$ between the particle number concentration of summer and winter measurement only occur for the lowest overlapping $T_{\mathrm{w}}$ range. The total measurement time per water tempera- ture bin was rather long (more than $1 \mathrm{~h}$ ), and therefore the difference cannot be explained by natural variability of the data. Since this offset is observed during the first hours of the experiment, it is likely that the system was not yet stable. The relatively large interquartile range between the 75th and 25th percentiles (971 particles $\mathrm{cm}^{-3}$ and 444 particles $\mathrm{cm}^{-3}$ for the water sampled close to the glacier and at the fjord mouth, respectively) observed for the summertime lowest $T_{\mathrm{w}}$ range also supports the conclusion that the system was unstable for these measurements.

Interestingly, the particles $D_{p}<0.250 \mu \mathrm{m}$ were more affected than the particles $D_{p}>0.250 \mu \mathrm{m}$. This indicates that the particles with $D_{p}<0.250 \mu \mathrm{m}$ and with $D_{p}>0.250 \mu \mathrm{m}$ are produced from different processes, and the instability is only influencing the process producing particles with $D_{p}<$ $0.250 \mu \mathrm{m}$, which predominantly originates from film drops. Figure $3 \mathrm{~d}$ shows that the ratio between particles with a $D_{p}>0.01 \mu \mathrm{m}$ and with a $D_{p}>0.250 \mu \mathrm{m}$ is a function of water temperature during wintertime but not during summertime. The ratio is also on average higher for summertime measurements compared to wintertime measurements. This results from a combination of both higher particle number concentrations for particles with a $D_{p}<0.250 \mu \mathrm{m}$ and lower particle number concentrations for particles with a $D_{p}>0.250 \mu \mathrm{m}$ during summertime. There are a number of possible reasons for this. Firstly, the water composition is different due to high biological activity during the summer season compared to the winter season. Secondly, the local sources of meltwater and river runoff in the fjord change with season, which possibly modified the measured particle concentrations at different sizes. Thirdly, a potentially important factor for substances present on the ocean surface is the vertical mixing of the water column, bringing material from different depths to the surface. Which, if any, of these factors, or combination of factors, led to the differences in the ratios between the measured particles with a $D_{p}>0.01 \mu \mathrm{m}$ and with a $D_{p}>0.250 \mu \mathrm{m}$ between summer- and wintertime measurements is impossible to say with the data available from this study.

Although a consistent dependency of the particle number concentration on water temperature was observed for the two seasons, there are significant differences between summer and winter particle number size distributions for the overlapping water temperature ranges (excluding Figs. 4a and 5a for which a not yet stable setup system can be assumed). For measurements based on fjord mouth water representing open sea conditions, higher particle number concentrations of particles smaller than about $D_{p} 0.125 \mu \mathrm{m}$ were registered in summer. However, this feature was not observed for measurements based on water sampled close to the glacier. One possible explanation is that photoautotrophic species are a source of material, likely of organic nature, which is important for formation of small sea spray particles. The availability of light is often considered to be the limiting factor for phytoplankton growth (Hop et al., 2002; Hodal et al., 

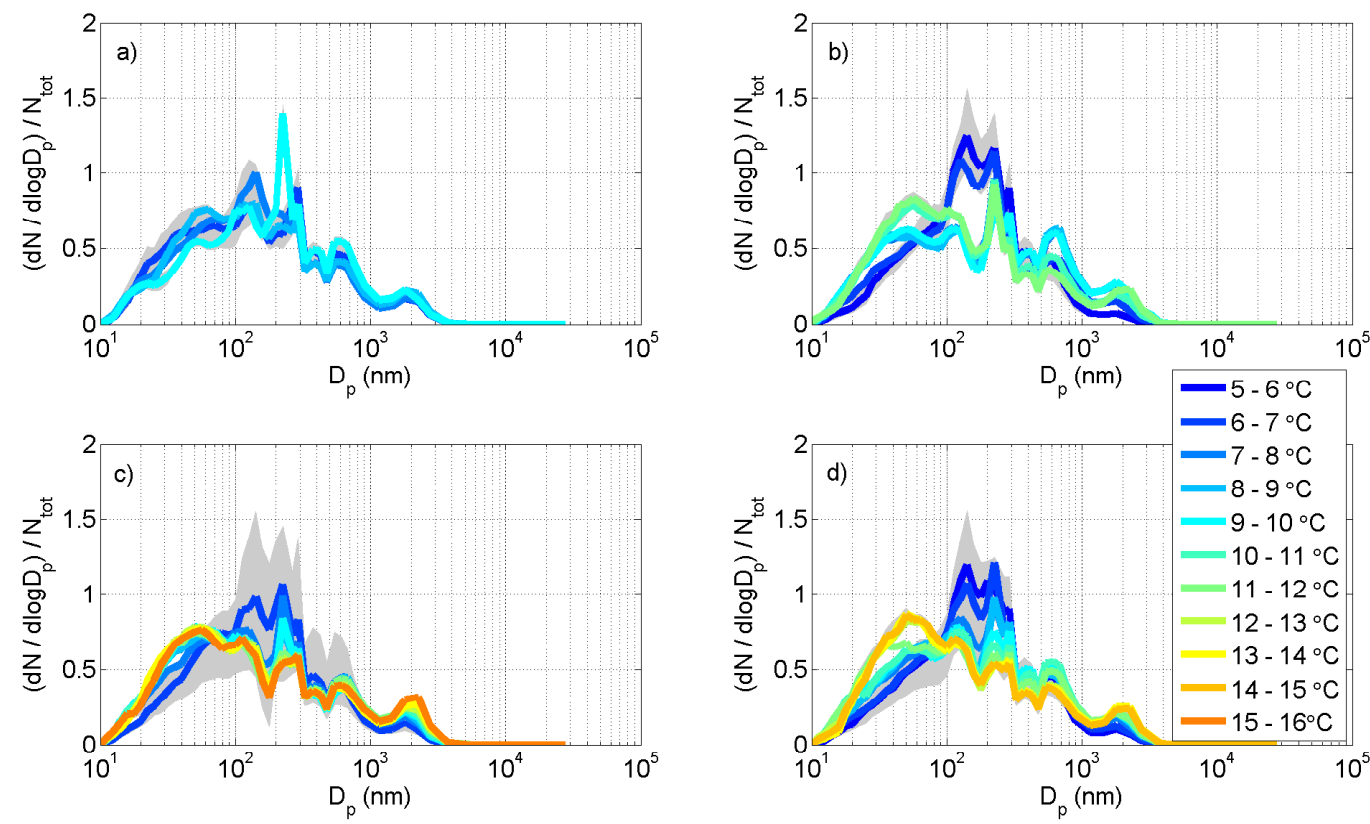

Fig. 10. Normalized number size distributions for summer experiments resulting from bubble bursting of (a) deep fjord water, (b) water sampled close to the glacier, (c) water sampled at the fjord mouth and (d) water sampled at the middle of the fjord. Grey shaded areas represent the interquartile range for the lowest and highest water temperature range. The same grey shade is used for both temperature ranges and indicates if there is an obvious difference between the particle number concentrations of different sizes of the lowest and highest water temperature.
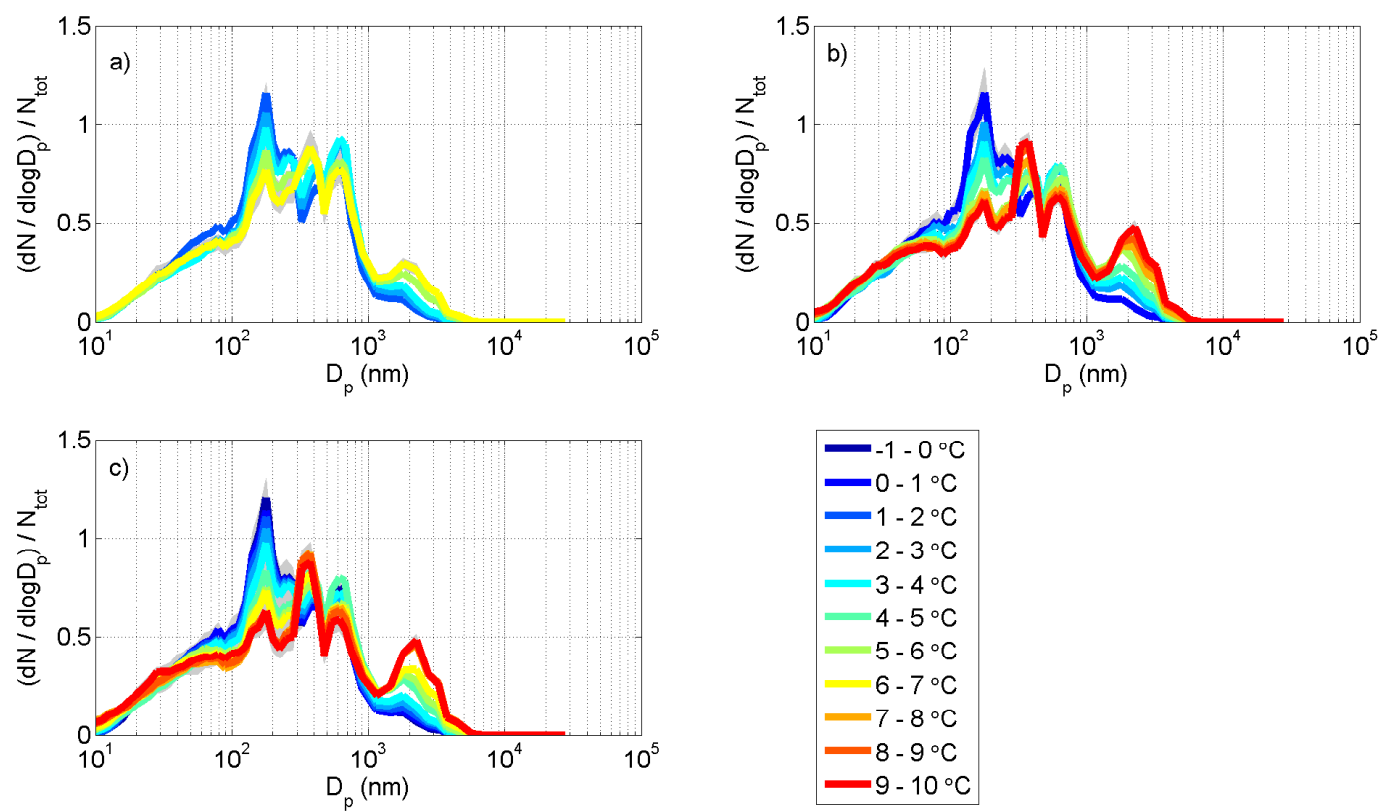

Fig. 11. Normalized number size distributions for winter experiments resulting from bubble bursting of (a) deep fjord water, (b) water sampled close to the glacier and (c) water sampled at the fjord mouth. Grey shaded areas represent the interquartile range for the lowest and highest water temperature range. The same grey shade is used for both temperature ranges and indicates if there is an obvious difference between the particle number concentrations of different sizes of the lowest and highest water temperature. 
Table 2. Parameters for fitted log-normal aerosol number size distributions, where $\mathrm{Nx}$ is the number concentration $\left(\mathrm{cm}^{-3}\right), \operatorname{Dgx}$ the geometric diameter $(\mu \mathrm{m})$ and $\sigma \mathrm{x}$ the standard deviation for the different modes and seasons.

\begin{tabular}{lcc}
\hline & winter & summer \\
\hline $\mathrm{N} 1$ & 129 & 182 \\
$\mathrm{Dg} 1$ & 0.063 & 0.067 \\
$\sigma 1$ & 2.48 & 2.48 \\
\hline $\mathrm{N} 2$ & 22 & 28 \\
$\mathrm{Dg} 2$ & 0.164 & 0.227 \\
$\sigma 2$ & 1.19 & 1.08 \\
\hline $\mathrm{N} 3$ & 132 & 58 \\
$\mathrm{Dg} 3$ & 0.43 & 0.575 \\
$\sigma 3$ & 1.54 & 1.50 \\
\hline $\mathrm{N} 4$ & 58 & 18 \\
$\mathrm{Dg} 4$ & 2.1 & 1.8 \\
$\sigma 4$ & 1.42 & 1.34 \\
\hline
\end{tabular}

2012). The waters close to the glacier are characterized by high sediment loads during summer, which weakens the penetration of sunlight into the water column inhibiting the activity of photoautotrophic species (Hop et al., 2002; Svendsen et al., 2002). Several studies showed that, during phytoplankton blooms in the North Atlantic, the submicron primary marine aerosol (PMA) is enriched with organic matter compared to the super-micrometer particles (Cavalli et al., 2004; O'Dowd et al., 2004; Facchini et al., 2008). Fuentes et al. (2010b) observed an increase in the production of particles with $D_{p}<100 \mathrm{~nm}$ and a shift towards smaller particle sizes with an increase of a phytoplankton bioexudate concentration in a sea water proxy. If this observation is transferable to our experiments, it would result in a relatively lower small particle production from water sampled close to the glacier compared to the particle production from open sea water. Another explanation is that the water sampled close to the glacier is mostly meltwater (as surface water was sampled) and, therefore, does not contain as much biological material as the water sampled at the fjord mouth. This is supported by the particle number size distribution resulting from deep fjord water, which resembles the size distributions from water close to the fjord mouth. Since no chemical analysis of the sampled aerosol was made in this work, we cannot determine whether organic material from phytoplankton influenced the particle number size distribution.

The increase in the number of smaller particles during summer forms a contrast to the observed relative increase in particle number concentrations of larger particles with an increase in $T_{\mathrm{w}}$ during winter measurements (Figs. 10 and 11). Besides biological production in summer and local effects (sea ice formation, different sediment loads), changes in water characteristics between the two seasons may also occur due to different contributions by Arctic and Atlantic waters. During the winter months, the water in Kongsfjorden is more influenced by Arctic water, while during summertime Atlantic water dominates the water mass in the fjord. In this context, it is interesting to note that the dominance of one specific water mass during each season may change in the future due to a changing climate. However, to date no significant change in the water volume of Atlantic water supplying the West Spitsbergen Current has been observed (Beszczynska-Møller et al., 2012).

A relationship between particle number concentration and water temperature has been reported in previous studies (e.g. Mårtensson et al., 2003; Hultin et al., 2011; Bowyer et al., 1990). However, to our knowledge no comparison between particle number concentration and size distributions resulting from biologically productive (summer conditions) and less biologically productive (winter conditions) waters has been made. Our study finds differences in aerosol characteristics between summer and winter measurements. However, predictions of future aerosol characteristics resulting from an increase in water temperature caused by climate change are difficult. The warming rates of about $1-2{ }^{\circ} \mathrm{Ch}^{-1}$ during the experiments represent more or less instantaneous temperature changes which cannot be directly compared to the slow changes expected by climate change. Long-term changes in biological and chemical processes occurring in the real Arctic Ocean are not captured by our experiments.

\section{Future implications}

The decrease in Arctic sea ice extent due to climate warming will be followed by changes in a number of different processes, which eventually will lead to different feedbacks. Figure 12 displays a potential feedback loop focused on processes closely related to PMA production and changes in sea ice cover (marked in red). For the sake of completeness, we have also included one BVOC emission process loop (biogenic volatile organic compounds; which also include dimethylsulphide (DMS)) in the figure (marked in green). It is worth reiterating that our results are based on laboratory experiments and therefore lack the interdependencies that may occur in the Arctic environment. However, to our knowledge no existing in situ measurements have been reported in the literature. As such we feel it is appropriate to base our discussion on possible Arctic feedbacks on our laboratory measurements. With this caveat in mind, it should be noted that Fig. 12 only serves to exemplify key pathways and does not represent all possible feedback processes related to aerosol direct and indirect effects that may be affected by climate change in the region. Following discussion of the feedback loop, analysis of those parameters which are expected to alter with climate change is conducted. However, these parameters are not included in the figure to retain clarity. The decrease in Arctic sea ice extent, which follows a warming of the Arctic, will influence parameters controlling the production of 


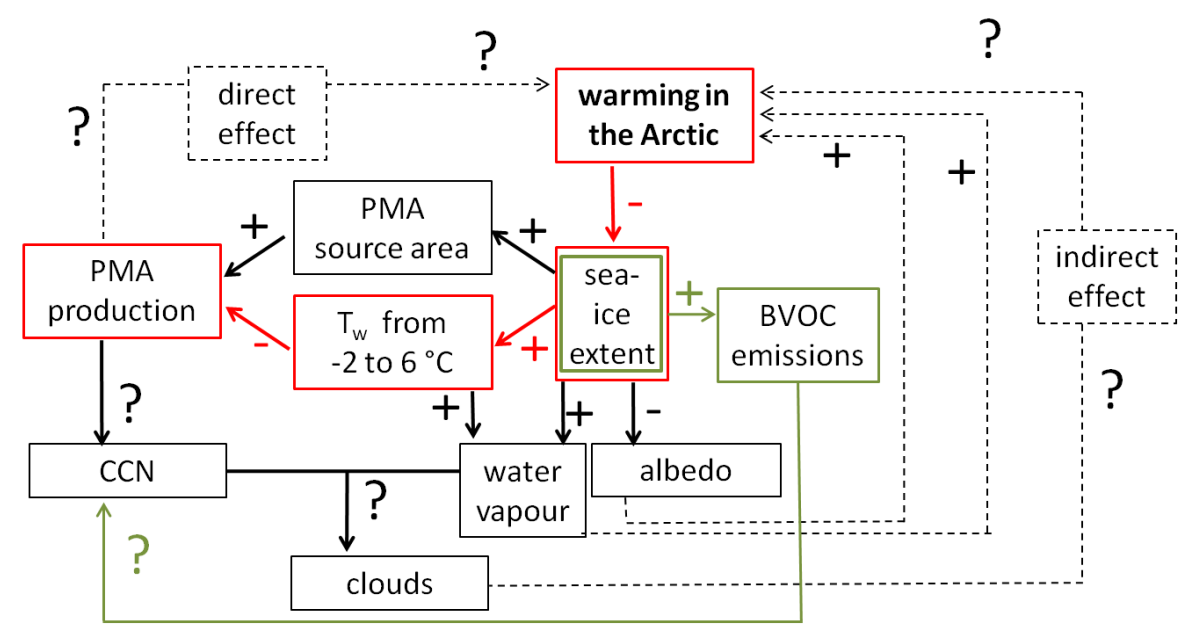

Fig. 12. Potential feedback loop resulting from a warming in the Arctic. Plus signs indicate increases, and minus signs indicate decreases. Question marks indicate that the direction of the change is not clear. The focus of this study is marked by the red colour. The green colour indicates the path related to changes in BVOC emissions.

primary and secondary marine aerosols (Fig. 12). These factors are the increase of the PMA source region, an increase in sea surface temperature (with subsequent effects on PMA production as presented within this study), and an increase in BVOC emissions, those precursor gases responsible for secondary marine aerosol production.

If sea surface temperature changes in the region $T_{\mathrm{W}}>$ $\sim 6^{\circ} \mathrm{C}$, no sea ice will be present and no change of PMA due to a change in source area will occur. If the results of our laboratory studies are correct, there will also be little effect of sea surface temperature changes on PMA production at these temperatures as effects here are minimal (cf. Sect. 3.1). Assuming a change of $T_{\mathrm{w}}$ in the lower water temperature range $\left(T_{\mathrm{w}}<\sim 6^{\circ} \mathrm{C}\right)$, the net resulting change in the PMA production due to the two factors (increasing $T_{\mathrm{w}}$ and increasing source area) is currently unknown (due to their opposing sign on PMA production). This issue therefore merits further studies, for example using modelling tools, as well as including additional parameters other than $T_{\mathrm{w}}$ that may impact on PMA production. It is likely that there will be a region that experiences sea surface temperature changes in the range between seawater ice formation and $T_{\mathrm{w}} \approx 6^{\circ} \mathrm{C}$. In a scenario with no or rather limited sea ice extent, PMA production will mainly be affected by the temperature trend.

The change in PMA production has important implications for the number of available cloud condensation nuclei (CCN) in the Arctic region. An increase in water temperature below $\sim 6^{\circ} \mathrm{C}$ will likely decrease the PMA number concentration and, subsequently, the amount of potential CCN (cf. Zábori et al., 2012a). In addition to this, our results highlight that the temperature-dependent relative PMA number size distribution is changing in the same direction for the accumulation mode but in different directions for the Aitken and coarse mode for aerosols produced by water sampled during wintertime and summertime. An increase in water temperature (from 5 to $13^{\circ} \mathrm{C}$ for summer experiments and from -1 to $9^{\circ} \mathrm{C}$ for winter experiments) reduces the relative particle number concentration in the accumulation mode, i.e. those particles that are most efficient as CCN. The different changes for the Aitken and coarse mode for the different seasons may affect the particle dynamics and consequently the amount of $\mathrm{CCN}$ which can be activated into cloud droplets.

Besides primary marine aerosols, the importance of secondary marine aerosols as $\mathrm{CCN}$ is currently being discussed extensively in the literature. Conclusions on the role of DMS for CCN production are ambiguous. Charlson et al. (1987) showed that the CCN number was affected by DMS emissions; however, other studies have found only sporadic or no correlation between DMS and CCN (e.g. Bates et al., 1992 and Berresheim et al., 1993 in Kloster et al., 2006). Gabric et al. (2005) modelled the DMS production in the Arctic Ocean as a result of a $\mathrm{CO}_{2}$ tripling up to the year 2080. DMS emissions were shown to increase considerably, mainly due to the decrease of the sea ice extent and the resulting decrease in the ocean-atmosphere exchange barrier. Besides DMS, other BVOCs are suspected to be precursors of secondary aerosols, e.g. isoprene (Vaattovaara et al., 2006). A study modelling the Arctic Ocean has highlighted the importance of both DMS and other BVOCs for new particle formation (Karl et al., 2012). Despite these hints it is our opinion that the factors influencing BVOC emissions in the Arctic Ocean are not well enough constrained to discuss the potential influence of climate change (see Shaw et al., 2010, for a review of marine isoprene and monoterpene emissions).

Our limited understanding of Arctic CCN characteristics and their potential response to a changing climate affects 
our ability to predict future aerosol-related changes in cloud cover. The supersaturation of water vapour in the atmosphere, atmospheric dynamics and the availability, size, and composition of CCN determine if and where cloud droplets and clouds form. The amount of water vapour in the Arctic atmosphere is dependent on sea ice cover, sea surface temperature and air temperature. Lower sea ice cover coincident with an increase in sea surface temperature should result in an increased transport of water vapour to the atmosphere given that the sea ice represents an evaporation barrier for the water and higher sea surface temperatures will increase evaporation rates. As the air temperature increases, more water vapour can remain in the atmosphere before condensation occurs, consequently intensifying Arctic warming.

A further parameter besides PMA source area, sea surface temperature, BVOC emissions, and water vapour that is influenced by a decreasing sea ice extent is the surface albedo, which decreases with decreasing sea ice cover. This decrease in surface albedo is coincident with increases in water vapour, an unknown change in PMA production and the subsequent unknown change in cloud properties close the feedback loop and impact on the warming of the Arctic. Both the decrease in surface albedo and the increase in water vapour are expected to have a positive feedback on the warming of the Arctic.

It is impossible to assess the net sign and magnitude for all the feedbacks in the warming Arctic linked to changes of sea ice coverage and PMA production at this point. Nevertheless we can speculate that the non-linear relation between PMA production and increasing sea surface temperatures in concert with changes in sea ice cover has a strong potential to contribute to the evolution of the Arctic climate and deserves future attention.

As previously mentioned, the feedback loop presented in Fig. 12 only considers a small fraction of those factors important for marine aerosol production in the Arctic. What follows is a discussion of other parameters that may impact on PMA production in the Arctic Ocean.

The salinity of the Arctic Ocean is expected to decrease in the future for a number of different reasons; at local scales a negative mass balance of glaciers has been observed (Nuth et al., 2010). This results in a decrease in the salinity of ocean surface water. It has also been suggested that an interplay between wind fields, melting sea ice and river runoff may lower salinities in the Arctic Ocean (Giles et al., 2012; MacDonald et al., 2002). The effect of salinity on PMA is unclear. Zábori et al. (2012a) did not observe a clear trend of particle number concentrations with salinity changes between 26 and $36 \%$ when conducting experiments with Arctic Ocean water. However, a number of other studies have shown that higher salinities can result in higher particle number concentrations (Mårtensson et al., 2003; Tyree et al., 2007; Hultin et al., 2011). Nevertheless these case experiments were conducted outside the Arctic.
An increase in water temperature affects the production of gas bubbles in the water. These gas bubbles produce aerosols when rising and bursting on the ocean surface. Thorpe et al. (1992) concluded that the temperature-related decrease in gas solubility and the temperature-related increase in molecular diffusivity cancel out and that the net effect of a temperature increase is a decrease in bubble concentrations due to a reduction in viscosity. However, a water-temperatureindependent change in oxygen saturations in the water occurs due to a change in photosynthesis rates. Since altered environmental conditions caused by climate change may impact the flora and fauna in the Arctic (Wassmann and Reigstad, 2011; Tremblay et al., 2011), a future change in oxygen saturation is likely to take place. Zábori et al. (2012a) did not observe a change in PMA number production with a change in oxygen saturation between 72 and $83 \%$ for Arctic Ocean conditions. Hultin et al. (2011) observed for Baltic Sea water an anti-correlation between particle production and oxygen saturations in the range 90 to $100 \%$. Thus, it is not possible to derive a clear conclusion on the role of oxygen saturation on PMA production.

The concentration of organic substances in the water is known to impact PMA production. Depending on the substance used, differences in total particle number concentrations and shifts in particle number size distributions have been observed. Experiments with dissolved organic carbon and colloidal organic matter (exudates of algae) have produced a shift of the size distribution towards smaller particle sizes relative to artificial inorganic seawater (Fuentes et al., 2010b). Tyree et al. (2007) observed an increase in total particle number concentration with an increase in the concentration of oleic acid. Zábori et al. (2012b) observed a decrease in total particle number concentration with an increase in the concentration of succinic acid. Clearly the influence of organic substances on PMA is complex and there is a need for further well-designed experiments to aid understanding.

Another important parameter for PMA production that is impossible to assess in laboratory experiments using water jets is the wind speed. It has been shown that PMA production is a non-linear function of wind speed (Lovett, 1978; Nilsson et al., 2001). Struthers et al. (2011) simulated the sea salt emissions in a future Arctic climate, where the emissions were dependent on sea ice extent, sea surface temperature and the $10 \mathrm{~m}$ wind speed. An increase in sea salt emissions was observed with the effect driven predominantly by the decrease in sea ice extent and changes in sea surface temperature rather than from a change in wind speed. However, a change in wind speed is likely to change the organic composition of PMA. Gantt et al. (2011) developed a conceptual model describing the organic mass fraction of sea spray aerosols as a function of wind speed. As the wind speed exceeds $3-4 \mathrm{~ms}^{-1}$, the surface microlayer (a tens of nanometers to about $100 \mu \mathrm{m}$ thick layer on the ocean surface consisting of organic substances (Lion and Leckie, 1981; Cunliffe et al., 2013)) starts to become mixed with subsurface water, and at 
wind speeds larger than $8 \mathrm{~ms}^{-1}$ a homogeneous water column is expected, resulting in lower organic mass fractions of sea spray aerosols. Transferred to our experiments, this means that possible PMA organic fractions in the aerosols are dependent not only on the production of the organic substances in water, but also on the mixing in the water column.

Additional factors potentially important for the climate feedback loop shown in Fig. 12 are an increase in the maritime transportation, tourism, and oil exploration activity as a result of an increasingly ice-free Arctic Ocean. These will result in increasing anthropogenic aerosol emissions and the release of substances into the Arctic Ocean water.

Our attempt is to present a rather simplified scheme of possible feedbacks linked to PMA production from the Arctic Ocean and sea water properties. There are numerous other processes influencing the ocean-atmosphere interactions. Some of them were discussed in the text and some of them not at all, like impact of broader scale processes outside the Arctic linked to the atmospheric and ocean general circulation.

\section{Summary and conclusions}

During previous laboratory experiments with Arctic Ocean water sampled during wintertime at Kongsfjorden/western Spitsbergen, an increase of water temperatures close to the freezing point was found to give a decrease in the particle number concentration (Zábori et al., 2012a). The present study aims to determine if this trend is consistent with laboratory measurements conducted using Arctic Ocean water with higher water temperatures sampled during summertime, despite an expected difference in the content of organic material in water, different local processes and differences in water masses within the fjord (e.g. sea ice production in winter and increased glacial meltwater inflow during summer) and different origin of the dominant water mass between the two seasons.

To this end, we measured total particle number concentrations as a function of water temperature and compared the different seasons using water sampled at the fjord mouth, close to the glacial front and from a permanent deep water inlet. In addition, particle number size distributions were compared for the overlapping water temperature ranges between summer- and wintertime. Normalized particle number size distributions as a function of water temperature were also examined over the whole water temperature range for both seasons.

Key findings are summarized below:

1. The trend in total particle number concentrations as a function of water temperature is consistent between summer and winter measurements.

2. Particle number concentrations decrease by $4-5$ times with increasing $T_{\mathrm{w}}$ from about $1^{\circ} \mathrm{C}$ to $6^{\circ} \mathrm{C}$ (for particles with $\left.D_{p}>0.01 \mu \mathrm{m}\right)$. For higher water temperatures, the concentrations remain relatively constant.

3. For overlapping water temperature bins, median particle number concentrations resulting from water sampled during summertime are similar or up to $70 \%$ higher than during wintertime for particles with $D_{p}<$ $0.125 \mu \mathrm{m}$. For $D_{p}>0.125 \mu \mathrm{m}$, the particle number concentrations during winter were mostly higher than in summer (up to $50 \%$ ).

4. During both seasons, a decrease in the relative particle number concentration for $D_{p} 0.100-0.300 \mu \mathrm{m}$ with increasing $T_{\mathrm{w}}$ is observed. At the same time, a relative increase of particles with $D_{p}>1 \mu \mathrm{m}$ and $D_{p}<0.100 \mu \mathrm{m}$ is observed for winter and summer measurements, respectively.

5. Changes in direct and indirect effects of primary marine aerosols may occur as a consequence of decreasing sea ice extent. These changes are in turn likely to depend on the sea water temperature range. The sign of the feedback resulting from a change in primary marine aerosol production may therefore be different for summer- and wintertime conditions in the Arctic.

Acknowledgements. We would like to thank the Kings Bay Marine Laboratory, Norwegian Polar Institute (NPI) staff and Kai Rosman for their support during the field experiment at $\mathrm{Ny}$-Ålesund. The Norwegian Meteorological Institute is acknowledged for providing the meteorological data. This work was funded by the Swedish Research Council FORMAS and supported by the Finnish Cultural Foundation through the Lapland regional fund and by the Magnus Ehrnrooth foundation. The European Centre for Arctic Environmental Research in Ny-Ålesund (ARCFAC V) is acknowledged for support (ARCFAC-026129-2009-39), as well as the Cryosphere-atmosphere interactions in a changing Arctic climate (CRAICC) initiative and the Swedish Polar Research Secretariat for providing field equipment.

Edited by: M. Boy

\section{References}

Bates, T. S., Calhoun, J. A., and Quinn, P. K: Variations in the methanesulfonate to sulfate molar ratio in submicrometer marine aerosol-particles over the South-Pacific ocean, J. Geophys. Res., 97, 9859-9865, 1992.

Berresheim, H., Eisele, F. L., Tanner, D. J., McInnes, L. M., Ramseybell, D. C., and Covert, D. S.: Atmospheric sulfur chemistry and Cloud Condensation Nuclei (CCN) concentrations over the northeastern Pacific coast, J. Geophys. Res., 98, 12701-12711, 1993. 
Beszczynska-Møller, A., Fahrbach, E., Schauer, U., and Hansen, E.: Variability in Atlantic water temperature and transport at the entrance to the Arctic Ocean, 1997-2010, ICES J. Mar. Sci., 69, 852-863, 2012.

Bowyer, P. A., Woolf, D. K., and Monahan, E. C.: Temperature dependence of the charge and aerosol production associated with a breaking wave in a whitecap simulation tank, J. Geophys. Res.Oceans, 95, 5313-5319, doi:10.1029/JC095iC04p05313, 1990.

Cavalli, F., Facchini, M. C., Decesari, S., Mircea, M., Emblico, L., Fuzzi, S., Ceburnis, D., Yoon, Y. J., O’Dowd, C. D., Putaud, J.-P., and Dell'Acqua, A.: Advances in characterization of size-resolved organic matter in marine aerosol over the North Atlantic, J. Geophys. Res.-Atmos., 109, D24215, doi:10.1029/2004JD005137, 2004.

Charlson, R. J., Lovelock, J. E., Andreae, M. O., and Warren, S. G.: Oceanic phytoplankton, atmospheric sulphur, cloud albedo and climate, Nature, 326, 655-661, doi:10.1038/326655a0, 1987.

Comiso, J. C., Parkinson, C. L., Gersten, R., and Stock, L.: Accelerated decline in the Arctic sea ice cover, Geophys. Res. Lett., 35, L01703, doi:10.1029/2007GL031972, 2008.

Cunliffe, M., Engel, A., Frka, S., Gašparović, B., Guitart, C., Murrell, J. C., Salter, M. E., Stolle, C., Upstill-Goddard, R. C., Wurl, O.: Sea surface microlayers: A unified physicochemical and biological perspective of the air-ocean interface, Prog. Oceanogr., 109, 104-116, doi:/10.1016/j.pocean.2012.08.004, 2013.

Facchini, M. C., Rinaldi, M., Decesari, S., Carbone, C., Finessi, E., Mircea, M., Fuzzi, S., Ceburnis, D., Flanagan, R., Nilsson, E. D., de Leeuw, G., Martino, M., Woeltjen, J., and O'Dowd, C. D.: Primary submicron marine aerosol dominated by insoluble organic colloids and aggregates, Geophys. Res. Lett., 35, L17814, doi:10.1029/2008GL034210, 2008.

Fuentes, E., Coe, H., Green, D., de Leeuw, G., and McFiggans, G.: Laboratory-generated primary marine aerosol via bubble-bursting and atomization, Atmos. Meas. Tech., 3, 141162, doi:10.5194/amt-3-141-2010, 2010a.

Fuentes, E., Coe, H., Green, D., de Leeuw, G., and McFiggans, G.: On the impacts of phytoplankton-derived organic matter on the properties of the primary marine aerosol - Part 1: Source fluxes, Atmos. Chem. Phys., 10, 9295-9317, doi:10.5194/acp-10-92952010, 2010b.

Gabric, A. J., Qu, B., Matrai, P., and Hirst, A. C.: The simulated response of dimethylsulfide production in the Arctic Ocean to global warming, Tellus, 57B, 391-403, 2005.

Gantt, B., Meskhidze, N., Facchini, M. C., Rinaldi, M., Ceburnis, D., and O'Dowd, C. D.: Wind speed dependent size-resolved parameterization for the organic mass fraction of sea spray aerosol, Atmos. Chem. Phys., 11, 8777-8790, doi:10.5194/acp-11-87772011, 2011.

Giles, K. A., Laxon, S. W., Ridout, A. L., Wingham, D. J. and Bacon, S.: Western Arctic Ocean freshwater storage increased by wind-driven spin-up of the Beaufort Gyre, Nature Geosci., 5, 194-197, doi:10.1038/ngeo1379, 2012.

Hodal, H., Falk-Petersen, S., Hop, H., Kristiansen, S., and Reigstad, M.: Spring bloom dynamics in Kongsfjorden, Svalbard: nutrients, phytoplankton, protozoans and primary production, Polar Biol., 35, 191-203, doi:10.1007/s00300-011-1053-7, 2012.
Hop, H., Pearson, T., Hegseth, E. N., Kovacs, K. M., Wiencke, C., Kwasniewski, S., Eiane, K., Mehlum, F., Gulliksen, B., Wlodarska-Kowalezuk, M., Lydersen, C., Weslawski, J. M., Cochrane, S., Gabrielsen, G. W., Leakey, R. J. G., Lønne, O. J., Zajaczkowski, M., Falk-Petersen, S., Kendall, M., Wängberg, S.Å., Bischof, K., Voronkov, A. Y., Kovaltchouk, N. A., Wiktor, J., Poltermann, M., di Prisco, G., Papucci, C., and Gerland, S.: The marine ecosystem of Kongsfjorden, Svalbard, Polar Res., 21, 167-208, doi:10.1111/j.1751-8369.2002.tb00073.x, 2002.

Hop, H., Falk-Petersen, S., Svendsen, H., Kwasniewski, S., Pavlov, V., Pavlova, O., and Søreide, J. E.: Physical and biological characteristics of the pelagic system across Fram Strait to Kongsfjorden, Prog. Oceanogr., 71, 182-231, doi:10.1016/j.pocean.2006.09.007, 2006.

Hultin, K. A. H., Nilsson, E. D., Krejci, R., Mårtensson, E. M., Ehn, M., Hagström, Å., and de Leeuw, G.: In situ laboratory sea spray production during the Marine Aerosol Production 2006 cruise on the northeastern Atlantic Ocean, J. Geophys. Res.Atmos., 115, D06201, doi:10.1029/2009JD012522, 2010.

Hultin, K. A. H., Krejci, R., Pinhassi, J., Gomez-Consarnau, L., Mårtensson, E. M., Hagström, Å., and Nilsson, E. D.: Aerosol and bacterial emissions from Baltic Seawater, Atmos. Res., 99, 1-14, doi:10.1016/j.atmosres.2010.08.018, 2011.

Ito, H. and Kudoh, S.: Characteristics of Water in Kongsfjorden, Proc. NIPR Symp. Polar Meteorol. Glaciol., 11, 211-232, 1997.

Johannessen, O. M., Shalina, E. V., and Miles, M. W.: Satellite evidence for an Arctic sea ice cover in transformation, Science, 286, 1937-1939, doi:10.1126/science.286.5446.1937, 1999.

Karl, M., Leck, C., Gross, A., and Pirjola, L.: A study of new particle formation in marine boundary layer over the central Arctic ocean using a flexible multicomponent aerosol dynamic model, TellusB, 64, 1-24, 2012.

Kloster, S., Feichter, J., Maier-Reimer, E., Six, K. D., Stier, P., and Wetzel, P.: DMS cycle in the marine ocean-atmosphere system a global model study, Biogeosciences, 3, 29-51, 2006.

Lion, L. W. and Leckie, J. O.: The biogeochemistry of the air-sea interface, Annu. Rev. Earth Pl. Sc., 9, 449-486, doi:10.1146/annurev.ea.09.050181.002313, 1981.

Lovett, R. F.: Quantitative measurement of airborne sea-salt in the North Atlantic, Tellus, 30, 358-364, 1978.

MacDonald, R. W., McLaughlin, F. A., and Carmarck, E. C.: Fresh water and its sources during the SHEBA drift in the Canada basin of the Arctic Ocean, Deep-Sea Res. I, 49, 1769-1785, doi:10.1016/S0967-0637(02)00097-3, 2002.

Mårtensson, E. M., Nilsson, E. D., de Leeuw, G., Cohen, L. H., and Hansson, H.-C.: Laboratory simulations and parameterization of the primary marine aerosol production, J. Geophys. Res.-Atmos., 108, 4297, doi:10.1029/2002JD002263, 2003.

Modini, R. L., Ristovski, Z. D., Johnson, G. R., He, C., Surawski, N., Morawska, L., Suni, T., and Kulmala, M.: New particle formation and growth at a remote, sub-tropical coastal location, Atmos. Chem. Phys., 9, 7607-7621, doi:10.5194/acp9-7607-2009, 2009

Nilsson, E. D., Rannik, U., Swietlicki, E., Leck, C., Aalto, P. P., Zhou, J., and Norman, M.: Turbulent aerosol fluxes over the Arctic Ocean 2. Wind-driven sources from the sea, J. Geophys. Res.Atmos., 106, 32139-32154, doi:10.1029/2000JD900747, 2001.

Nuth, C., Moholdt, G., Kohler, J., Hagen, J. O., and Kääb, A.: Svalbard glacier elevation changes and contribution to 
sea level rise, J. Geophys. Res.-Earth, 115, F01008, doi:10.1029/2008JF001223, 2010.

O’Dowd, C. D., Facchini, M. C., Cavalli, F., Ceburnis, D., Mircea, M., Decesari, S., Fuzzi, S., Yoon, Y. J., and Putaud, J.P.: Biogenically driven organic contribution to marine aerosol, Nature, 431, 676-680, doi:10.1038/nature02959, 2004.

Parkinson, C. L. and Cavalieri, D. J.: Arctic sea ice variability and trends, 1979-2006, J. Geophys. Res.-Oceans, 113, C07003, doi:10.1029/2007JC004558, 2008.

Piehl Harms, A. A., Tverberg, V., and Svendsen, H.: Physical qualification and quantification of the water masses in the Kongsfjorden-Krossfjorden system cross section, in: Proceedings Paper, Oceans 07 IEEE Aberdeen, 061215-086, doi:10.1109/OCEANSE.2007.4302332, 2007.

Polyakov, I., Timokhov, L., Dmitrenko, I., Ivanov, V., Simmons, H., Beszczynska-Møller, A., Dickson, R., Fahrbach, E., Fortier, L., Gascard, J.-C., Hölemann, J., Holliday, N. P., Hansen, E., Mauritzen, C., Piechura, J., Pickart, R., Schauer, U., Steele, M., and Walczowski, W.: Observational program tracks Arctic Ocean transition to a warmer state, EOS T. Am. Geophys. Un., 88, 398399, doi:10.1029/2007EO400002, 2007.

Russell, L. M. and Singh, E. G.: Submicron salt particle production in bubble bursting, Aerosol Sci. Tech., 40, 664-671, doi:10.1080/02786820600793951, 2006.

Shaw, S. L., Gantt, B., and Meskhidze, N.: Production and Emissions of Marine Isoprene and Monoterpenes: A Review, Advances in Meteorology, 408696, 24 pp., 2010.

Steele, M., Ermold, W., and Zhang, J.: Arctic Ocean surface warming trends over the past 100 years, Geophys. Res. Lett., 35, L02614, doi:10.1029/2007GL031651, 2008.

Struthers, H., Ekman, A. M. L., Glantz, P., Iversen, T., Kirkevåg, A., Mårtensson, E. M., Seland, Ø., and Nilsson, E. D.: The effect of sea ice loss on sea salt aerosol concentrations and the radiative balance in the Arctic, Atmos. Chem. Phys., 11, 3459-3477, doi:10.5194/acp-11-3459-2011, 2011.

Svendsen, H., Beszczynska-Møller, A., Hagen, J. O., Lefauconnier, B., Tverberg, V., Gerland, S., Ørbøk, J. B., Bischof, K., Papucci, C., Zajaczkowski, M., Azzolini, R., Bruland, O., Wiencke, C., Winther, J.-G., and Dallmann, W.: The physical environment of Kongsfjorden-Krossfjorden, an Arctic fjord system in Svalbard, Polar Res., 21, 133-166, doi:10.1111/j.17518369.2002.tb00072.x, 2002.
Thorpe, S. A., Bowyer, P., and Woolf, D. K.: Some factors affecting the size distributions of oceanic bubbles, J. Phys. Oceanogr., 22, 382-389, doi:10.1175/15200485(1992)022<0382:SFATSD>2.0.CO;2, 1992.

Tremblay, J.-É., Bélanger, S., Barber, D. G., Asplin, M., Martin, J., Darnis, G., Fortier, L., Gratton, Y., Link, H., Archambault, P., Sallon, A., Michel, C., Williams, W. J., Philippe, B., and Gosselin, M.: Climate forcing multiplies biological productivity in the coastal Arctic Ocean, Geophys. Res. Lett., 38, L18604, doi:10.1029/2011GL048825, 2011.

Tyree, C. A., Hellion, V. M., Alexandrova, O. A., and Allen, J. O.: Foam droplets generated from natural and artificial seawaters, J. Geophys. Res.-Atmos., 112, D12204, doi:10.1029/2006JD007729, 2007.

Vaattovaara, P., Huttunen, P. E., Yoon, Y. J., Joutsensaari, J., Lehtinen, K. E. J., O’Dowd, C. D., and Laaksonen, A.: The composition of nucleation and Aitken modes particles during coastal nucleation events: evidence for marine secondary organic contribution, Atmos. Chem. Phys., 6, 4601-4616, doi:10.5194/acp-64601-2006, 2006.

Wassmann, P. and Reigstad, M.: Future Arctic Ocean seasonal ice zones and implications for pelagic-benthic coupling, Oceanography, 24, 220-231, 2011.

Zábori, J., Krejci, R., Ekman, A. M. L., Mårtensson, E. M., Ström, J., de Leeuw, G., and Nilsson, E. D.: Wintertime Arctic Ocean sea water properties and primary marine aerosol concentrations, Atmos. Chem. Phys., 12, 10405-10421, doi:10.5194/acp-12-10405-2012, 2012a.

Zábori, J., Matisāns, M., Krejci, R., Nilsson, E. D., and Ström, J.: Artificial primary marine aerosol production: a laboratory study with varying water temperature, salinity, and succinic acid concentration, Atmos. Chem. Phys., 12, 10709-10724, doi:10.5194/acp-12-10709-2012, 2012b.

Zhang, J.: Warming of the arctic ice-ocean system is faster than the global average since the 1960s, Geophys. Res. Lett., 32, L19602, doi:10.1029/2005GL024216, 2005. 